\title{
Urban aerosol number size distributions
}

\author{
T. Hussein ${ }^{1}$, A. Puustinen ${ }^{1}$, P. P. Aalto ${ }^{1}$, J. M. Mäkelä ${ }^{2}$, K. Hämeri ${ }^{1,3}$, and M. Kulmala ${ }^{1}$ \\ ${ }^{1}$ Department of Physical Sciences, University of Helsinki, P.O. Box 64, FIN-00014, UHEL, Finland \\ ${ }^{2}$ Institute of Physics, Tampere University of Technology, P.O. Box 692, FIN-33101 Tampere, Finland \\ ${ }^{3}$ Physics Department, Finnish Institute of Occupational Health, Topeliuksenkatu 41a A, FIN-00250 Helsinki, Finland
}

Received: 9 July 2003 - Published in Atmos. Chem. Phys. Discuss.: 16 October 2003

Revised: 13 February 2004 - Accepted: 18 February 2004 - Published: 1 March 2004

\begin{abstract}
Aerosol number size distributions have been measured since 5 May 1997 in Helsinki, Finland. The presented aerosol data represents size distributions within the particle diameter size range 8-400 $\mathrm{nm}$ during the period from May 1997 to March 2003. The daily, monthly and annual patterns of the aerosol particle number concentrations were investigated. The temporal variation of the particle number concentration showed close correlations with traffic activities. The highest total number concentrations were observed during workdays; especially on Fridays, and the lowest concentrations occurred during weekends; especially Sundays. Seasonally, the highest total number concentrations were observed during winter and spring and lower concentrations were observed during June and July. More than $80 \%$ of the number size distributions had three modes: nucleation mode $\left(D_{p}<30 \mathrm{~nm}\right)$, Aitken mode $(20-100 \mathrm{~nm})$ and accumulation mode $\left(D_{p}>90 \mathrm{~nm}\right)$. Less than $20 \%$ of the number size distributions had either two modes or consisted of more than three modes. Two different measurement sites were used; in the first (Siltavuori, 5.5.1997-5.3.2001), the arithmetic means of the particle number concentrations were $7000 \mathrm{~cm}^{-3}, 6500 \mathrm{~cm}^{-3}$, and $1000 \mathrm{~cm}^{-3}$ respectively for nucleation, Aitken, and accumulation modes. In the second site (Kumpula, 6.3.2001-28.2.2003) they were $5500 \mathrm{~cm}^{-3}$, $4000 \mathrm{~cm}^{-3}$, and $1000 \mathrm{~cm}^{-3}$. The total number concentration in nucleation and Aitken modes were usually significantly higher during workdays than during weekends. The temporal variations in the accumulation mode were less pronounced. The lower concentrations at Kumpula were mainly due to building construction and also the slight overall decreasing trend during these years. During the site changing a period of simultaneous measurements over two weeks were performed showing nice correlation at both sites.
\end{abstract}

Correspondence to: $\mathrm{M}$. Kulmala

(Markku.kulmala@helsinki.fi)

\section{Introduction}

Atmospheric aerosol particles in urban areas cause the loss of visibility (e.g. Finlayson-Pitts and Pitts, 2000) and health effects (Dockery and Pope, 1994). Heavily industrialized areas suffer from pollution fogs (smogs) that are often related to coal burning and nowadays also to traffic. The most wellknown example of such smogs is the London "pea-souper" smog, which occurred intermittently until the 50's, when coal burning was forbidden. Besides visibility degradation, the London smog episodes caused serious health effects and "excess deaths". A significant number of health problems related to atmospheric aerosols and fog droplets is believed to be due to particles having diameters less than $10 \mu \mathrm{m}$, because these particles can penetrate deep into the respiratory system (Dockery and Pope, 1994). Peters et al. (1997) have indicated that many of the pollution-related adverse health effects may be closely related to the presence of ultrafine airborne particles. Recently, the role of ultrafine particles $\left(D_{p}<100 \mathrm{~nm}\right)$ in health related issues has been discussed (e.g. Katsouyanni et al., 2001; Samet et al., 2000; Pope and Dockery, 1999).

Routine monitoring of airborne particulate matter has generally been performed using $\mathrm{PM}_{10}$ and $\mathrm{PM}_{2.5}$ measurements (mass of particulate matter smaller than 10 and $2.5 \mu \mathrm{m}$ in aerodynamic diameter). The number concentration and size distribution measurements are very rare. However, in rural areas there are several on-going measurements (see e.g. Mäkelä et al., 1997). In urban areas the results based on measurement campaigns have been typically reported. Wehner et al. (2002) performed particle size distribution measurements in a street canyon and Väkevä et al. (1999) measured the evolution of the number concentration also in a street canyon. Buzorius et al. (1999) studied the local and temporal variations of aerosol number concentrations in an urban area finding clear temporal variation with different frequencies. 

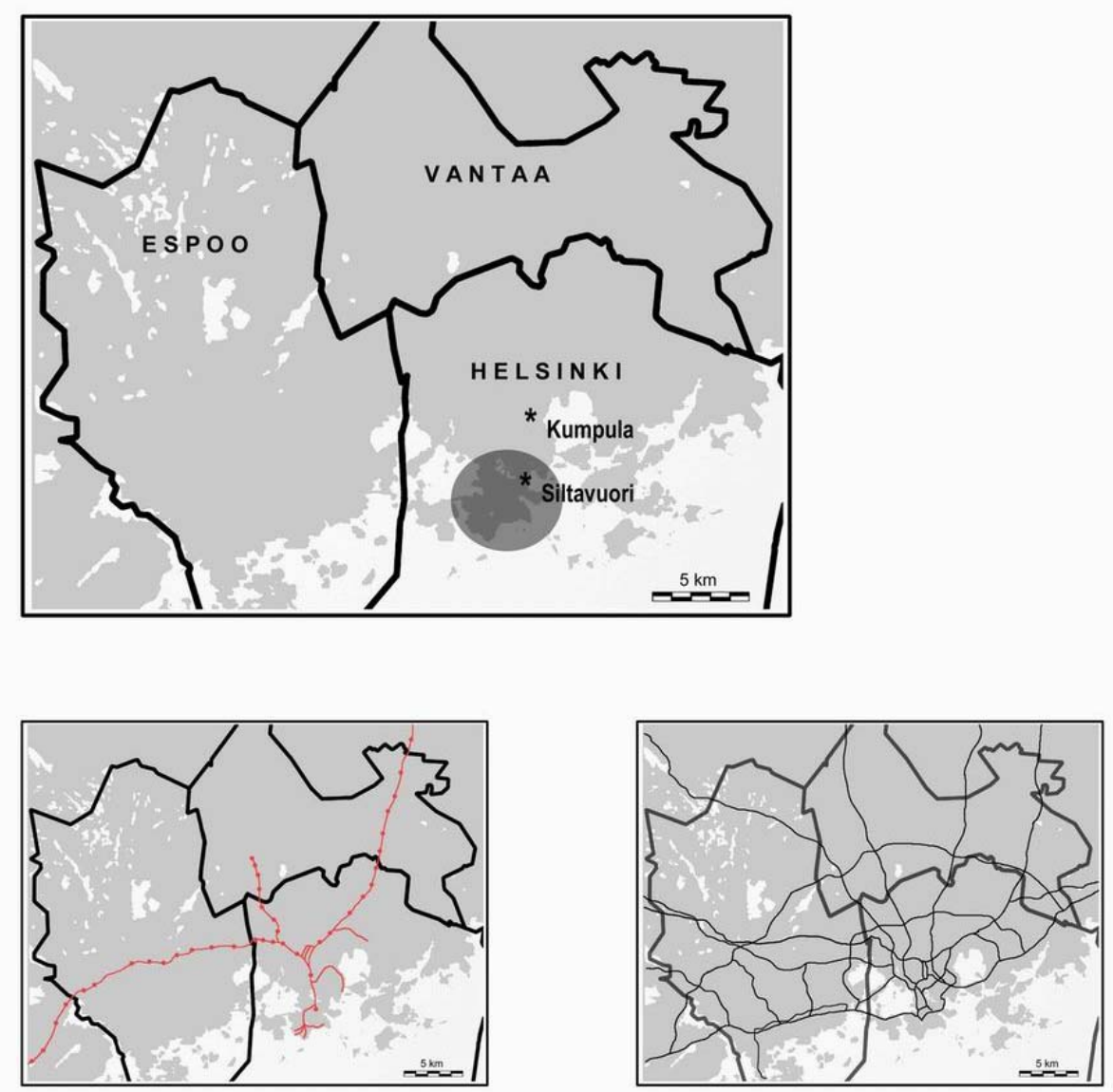

Fig. 1. A map of the Helsinki metropolitan area. The measurement site locations are indicated with a star in the (upper), and the dark circle is the downtown area. (Lower left) shows the railway routes, and (lower right) shows the main roads and highways. A more detailed map can be found from the Helsinki Area Council (YTV) web page (http://ilma.ytv.kaapeli.fi/english/research/area_map.php).

In rural areas typical aerosol particle concentrations are between 1000 and $10000 \mathrm{~cm}^{-3}$. In urban environments air quality is typically strongly influenced by motor vehicle emissions, and number concentrations of aerosol particles usually exceed $10^{4} \mathrm{~cm}^{-3}$. Harrison et al. (1999) found that particle number concentration was 7.5 times higher than the background level near a busy road in Bristol, $\mathrm{Rd}$ Birmingham. Based on size distribution measurements Shi et al. (2001) found significant amounts of nanoparticles $(<10 \mathrm{~nm})$ in the urban atmosphere. Most of the particles emitted by engines are in the ultrafine range (Kittelson, 1998), and therefore not directly influenced by industrial emissions in urban environments. Over $80 \%$ of the airborne particles in the urban air are in the ultrafine size range (Morawska et al., 1998b; Shi et al., 2001).

Ruuskanen et al. (2001) showed that the median (30 November 1996-13 March 1997) of the hourly mean total number concentration at an urban site in Helsinki was $20500 \mathrm{~cm}^{-3}$ (more than $80 \%$ were ultrafine particles), with a maximum value of about $145000 \mathrm{~cm}^{-3}$. In the same study (Ruuskanen et al., 2001), similar concentration lev- els were observed in two other European cities (Alkmaar in Netherlands and Erfurt in Germany). In Brisbane, Australia, the concentration of submicrometer particles correlated strongly with the concentrations of $\mathrm{NO}_{\mathrm{x}}$ and $\mathrm{CO}$ (Thomas and Morawska, 2002; Morawska et al., 1998b), suggesting that motor vehicle emissions constituted the main source of ultrafine particles. Under varying conditions, the number of emitted particles increased with increasing engine load, whereas the mean particle diameter decreased (Franz et al., 2000; Morawska et al., 1998a). In cities, cars are usually not driven at a constant speed; there is continuous acceleration and deceleration. In acceleration a higher number of smaller particles are probably emitted (Wehner et al., 2002).

Besides vehicles fuel combustions, industrial pollutants and long range transport (LRT) affect aerosol particle number and mass concentrations in urban areas. About 40-70\% of $\mathrm{PM}_{2.5}$ in Finland is assumed to result from LRT (Tiitta et al., 2002; Vallius et al., 2002). Accumulation mode particles can transport to long distances, whereas the lifetime of Aitken and nucleation mode particles is much smaller that makes them lost and not transported within a large scale. Due 
to coagulation and growth, nucleation mode particles may survive only for a few hours which correspond to a spatial scale of a maximum of a few hundred kilometers. Even if nucleation mode particles do not transport, the spatial scale of nucleation mode particles can still be thousands of kilometers (Mäkelä et al., 1998). The coarse fraction of $\mathrm{PM}_{10}$ do not normally travel more than a few tens of kilometers except for some special cases like Sahara dust episodes (Arimoto et al., 1995). In practice, LRT is affected by mesoscale meteorology. If the air masses come from areas with high emissions, air parcels contain more particles particularly in the accumulation mode (Kulmala et al., 2000). In Finnish conditions the position of the polar front is an important factor making changes to aerosol particle concentrations (Nilsson et al., 2001). The amount of particles which arrive at a certain location depends also on wet and dry deposition and cloud processes.

Meteorological conditions and seasonal changes have an influence on the aerosol particle emissions. In cities many people have their holidays in July which changes traffic emissions. On the other hand, in spring and summer higher concentration of aerosol precursor gases may allow photochemical reactions to produce condensable gases and subsequent nucleation and growth in urban air while it may be impossible in other conditions (Väkevä et al., 1999; Shi et al., 2001). Another example on the complexity is the background (regional) nucleation from urban areas. It increases particle concentration in cities even if the actual nucleation occurs in cleaner background areas. In this case particles grow due to higher urban pollutant concentrations, and the particle composition and mass will change.

The seasonal variation is well-known e.g. for re-suspended $\mathrm{PM}_{10}$ which is related to springtime snow smelting governing the release of sand from wintertime gravelling. Natural primary emissions like sea-spraying have a strong annual cycle related to wind speed and sea-ice cover. The seasonal effect is also related to house heating. Small scale biomass burning is a significant emission source during the winter especially in the countryside. Particle concentrations are also affected by local mixing. If the boundary layer is stable, locally emitted or re-suspended particles stay in a smaller volume (Väkevä et al., 2000). In practice, mixing depend on wind speed, turbulence, and relative humidity (Pohjola et al., 2000).

In spite of its importance, only some studies have concentrated on the seasonal variation of particulate mass $\left(\mathrm{PM}_{\mathrm{x}}\right)$ or number of aerosol particles using long-term measurements spanning over several months or even a few years (Havasi and Zlativ, 2002; Hussein et al., 2002; Kimmel et al., 2002; Morawska et al., 2002; Yang, 2002; Zhang et al., 2002). Long-term studies provide sufficient information on the aerosol characteristics. Recently, Laakso et al. (2003) investigated the number and mass concentrations as well as correlations between different particle size classes (nucleation, Aitken, and accumulation modes) and between

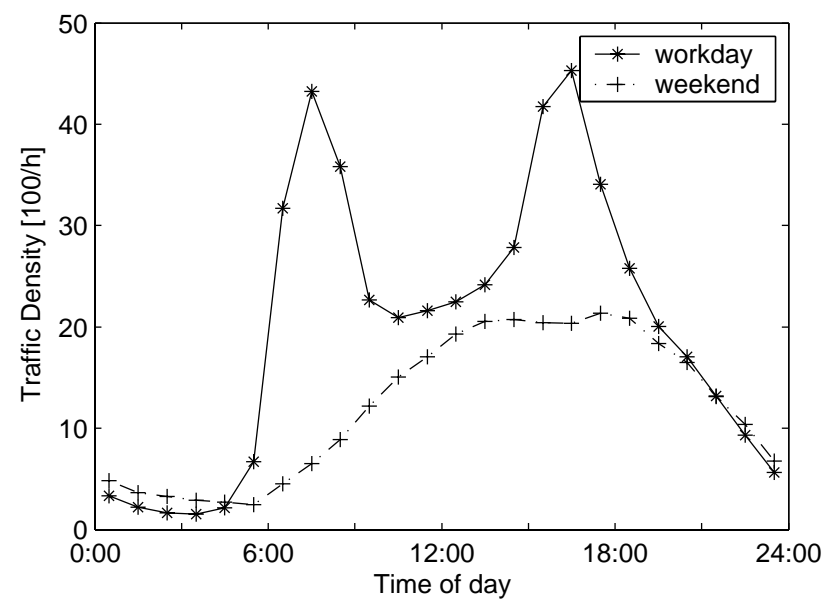

Fig. 2. Typical traffic density on a high way in Helsinki metropoli$\tan$ area.

number and mass concentrations in different regions (urban, suburban, forest, and rural) in Finland. On the other hand the long-term studies of aerosol size distributions are missing. The objective of the present study is to characterize the aerosol number size distributions in the Helsinki urban area during a long-term period (6 years, 1997-2003) with continuous monitoring of the number size distributions (diameter $<400 \mathrm{~nm}$ ). This includes investigations on (1) year-byyear temporal variation of both aerosol particle number concentration and size distributions, (2) the seasonal variation within each year, (3) the difference between daily patterns of workday and weekends of aerosol number concentration, and (4) the behavior of the modal structure of aerosol particles during different times in the year, season, and day.

\section{Methodology and experimental set-up}

\subsection{Measurement site location}

The number size distributions were measured in Helsinki $\left(60^{\circ} 10^{\prime} \mathrm{N}\right.$ and $\left.24^{\circ} 57^{\prime} \mathrm{E}\right)$; Finland. The measurements took place at the Physics Department of the Helsinki University, which was located on the bank hill Siltavuori. Siltavuori is approximately $20 \mathrm{~m}$ high peninsula that is located by the sea, and it was surrounded with urban sites including the downtown at a distance of a few hundred meters to the south west. Siltavuori is densely populated with residential and office buildings.

On 5 March 2001, the Physics Department was moved into a new building at Kumpula, which is located about $3 \mathrm{~km}$ north Siltavuori. The measurements were resumed in the forth floor of the new building, which was located on a hilltop ( $\sim 20 \mathrm{~m}$ high). At a distance of $200 \mathrm{~m}$, there was one of the major highways providing significant source of traffic emissions. The area itself was populated with residential buildings in the northeastern side, and to the west it was full 

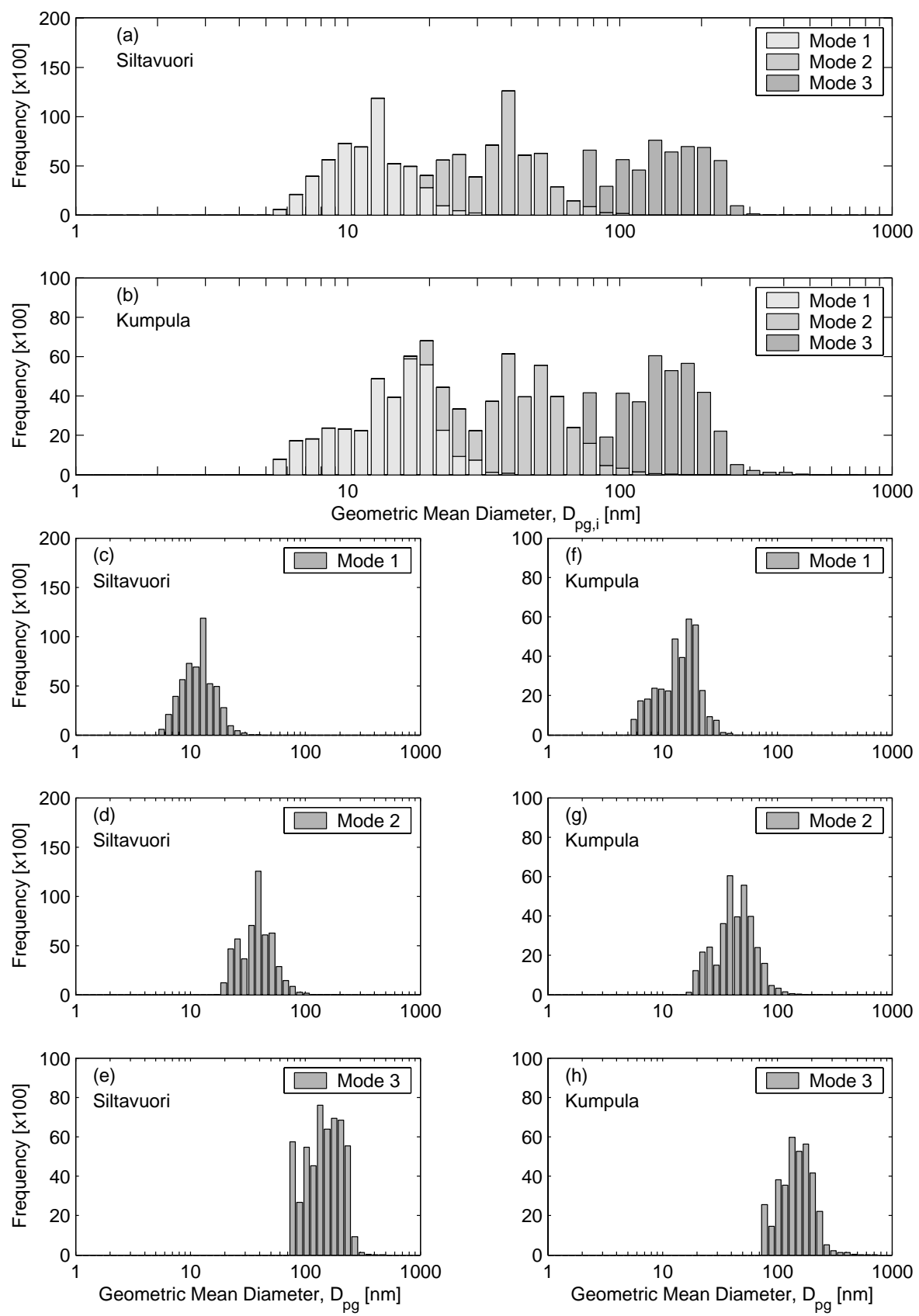

Fig. 3. Frequency histograms of the mode geometric mean diameter $\left(D_{p g, i}\right)(\mathbf{a})$ at Siltavuori, (b) at Kumpula. The histogram for each individual mode are presented in (c)-(e) at Siltavuori and (d)-(f) at Kumpula.

of greenswards and mainly small forest mixed with houses (see also Fig. 1). Siltavuori and Kumpula can be considered as urban sites.

\subsection{Aerosol particle measurements}

The ultrafine and fine particle number size distributions have been measured continuously (5-minutes resolution) with a differential mobility particle sizer (DMPS) since 5 May
1997. There have been several time periods when there was no measurements due to instrument maintenance. In the early stages of the measurement, the instruments were under testing, and hence the reliable data were obtained since December 1997. In the present study we investigate measured size distributions until 28 February 2003. 


\subsubsection{Measurement of particle number size distributions}

The differential mobility analysis of aerosol particles (e.g. Adachi et al., 1990; Winklmayr et al., 1991) instrumentation consisted of: (1) A bipolar charger for the particles, for which we used a $74 \mathrm{MBq}$ KR-85 neutralizer (Liu and Pui, 1974). (2) Differential mobility analyzer (electrostatic Classifier TSI 3071) to classify particles according to their electrical mobility (Knutson and Whitby, 1975). (3) Condensation Particle Counter (CPC) TSI 3022 (Quant et al., 1992) that was Occasionally replaced by either CPC TSI 3025 (Kesten et al., 1991) or CPC TSI 3010 (Mertes et al., 1995).

The sampling line was approximately $2 \mathrm{~m}$ long Stainless Steel tube with $4 \mathrm{~mm}$ inner diameter. No special inlet was used; just a rain cover. The sheath flow of the classifier was 8.5 LPM and the aerosol flow was 1.5 LPM. The sheath flow was arranged as closed loop, the excess flow was circulated back to the classifier as sheath flow after drying and filtering (Jokinen and Mäkelä, 1997; Birmili et al., 1999). The excess flow rate was controlled with a critical orifice. The sheath flow pump was a diaphragm pump made by KNF. The sheath flow dryer acted as pulsation damper. The aerosol flow rate was controlled by the CPC's own pump. The measurement range covered a particle diameter range from $8 \mathrm{~nm}$ to $400 \mathrm{~nm}$ by using twenty channels. The waiting time after classifier voltage change was $15 \mathrm{~s}$ and after that particles were counted over a three second period. One measurement was then made in six minutes. There was some variation in the measurement range and time during the years.

In the weekly maintenance, aerosol and sheath flows were measured with a bubble flow meter and the CPC zero was checked by turning the classifier voltage to zero. Yearly maintenance included CPC and classifier calibration and thorough cleaning. CPC calibration included the particle detection efficiency calibration and the concentration calibration against the aerosol electrometer. Classifier calibration included transport loss calibration and the sizing accuracy calibration with PSL particles. The CPC was serviced and calibrated at the factory when needed.

\subsubsection{Raw data handling and uncertainties}

The raw data (voltage-concentration) had to be inverted in order to extract the particle size distribution. As input, the transfer function of the classifier had to be known as well as the particle charging probability, the CPC detection efficiency, and the transport losses in the sampling line and inside the classifier. For the transfer function we used functions by Stolzenburg (1988), and for charging probability the semi-empirical functions by Wiedensohler (1989). Transport line losses were calculated from the normal laminar flow tube diffusion loss equations, and for the classifier losses and CPC counting efficiency laboratory calibrations were implemented. The total losses for ten nanometer particles were

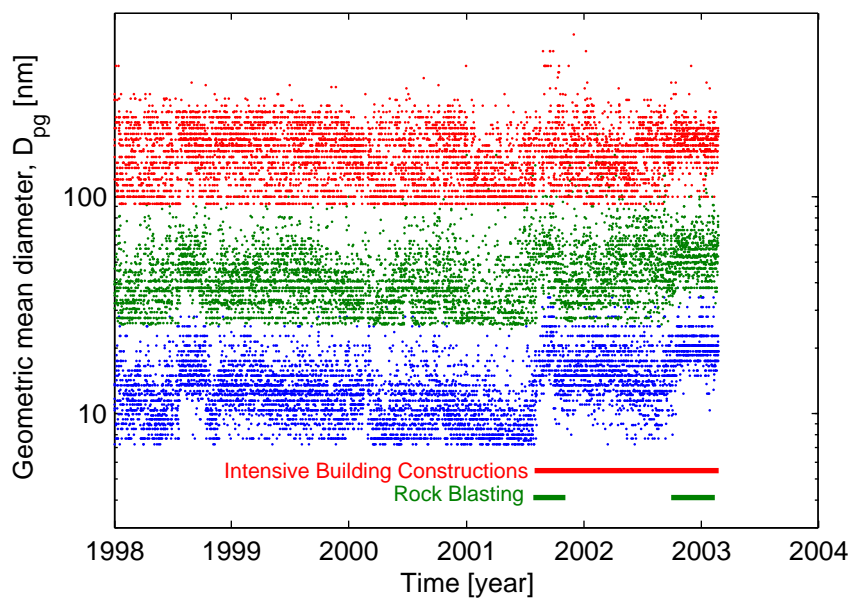

Fig. 4. Temporal variation of the mode geometric mean diameter at Siltavuori and Kumpula. The start of building construction is also indicated as well as the intensive rock blasting periods.

approximately $75 \%$. The inversion was done by using the MatLab non negative least squares (NNLS) algorithm.

The counting statistics caused uncertainty in the size distribution. The uncertainty was dependent on the amount of counted particles per channel and varied typically between two and ten percents. The uncertainties of transport efficiency calibration and classifier voltage setting accuracy caused error for particle sizes below $15 \mathrm{~nm}$. The degree of this uncertainty was not very well known. Error of one volt in the classifier voltage could cause an error of half a nanometer in sizing at ten nanometer particle diameter. The uncertainties in transport efficiency calibration were as large as ten percent. The cooperative action of all the uncertainties was complicated. Therefore, the results from the particle sizes below $15 \mathrm{~nm}$ must be treated with caution.

\subsection{Data analysis}

Aerosol data consisted of number size distributions (8$400 \mathrm{~nm}$ in diameter) during six years (1997-2003). This aerosol data is considered quite huge to analyze. It required careful handling and great care during the analysis. The first step of the data analysis was performed as follows:

1. The aerosol data was first stored in separate daily files; i.e. each year has 365 (366 for leap years) separate data files that contain the measured number size distributions.

2. The aerosol data was checked for quality assurance according to the reliability of the measurement and data inversion.

3. The data was prepared for processing, which required relatively long time. 
4. The data was accumulated in larger yearly files.

5. Half-hourly, hourly, daily, and monthly means, medians, standard deviations and several percentiles were evaluated.

6. The total number concentration of fine particles was integrated from the number size distributions.

7. The aerosol data showed lognormal distributions. Standard central measures were then either represented by the geometric mean (GM) and its geometric standard deviation (GSD), or simply the median. The arithmetic mean (AM) and arithmetic standard deviation (ASD) were not representative of the central measures. The GM and GSD were evaluated according to

$$
\begin{aligned}
& \log _{10}\left(G M_{x}\right)=\frac{1}{N_{x}} \sum_{i=1}^{N_{x}} \log _{10}\left(x_{i}\right) \\
& \log _{10}\left(G S D_{x}\right)=\frac{1}{N_{x}} \sum_{i=1}^{N_{x}}\left[\log _{10}\left(x_{i}\right)-\log _{10}\left(G M_{x}\right)\right]^{2} .
\end{aligned}
$$

where $\log _{10}$ is the base $10 \operatorname{logarithm}, G M_{x}$ and $G S D_{x}$ are respectively the geometric mean and geometric standard deviation of a group of variables $x$ that has $N_{x}$ elements.

The second step of the data analysis was performed as follows:

1. The data was investigated separately for workdays (Monday-Friday) and weekend (Saturday and Sunday).

2. The diurnal patterns were evaluated.

3. Seasonal analysis was performed.

4. The annual variation was investigated.

5. Multi-lognormal fitting was performed for the number size distributions.

Number size distributions were fitted to a multi-lognormal distribution function in the form (Seinfeld and Pandis, 1998)

$$
\begin{aligned}
& \frac{d N}{d\left(\log \left(D_{p}\right)\right)}= \\
& \sum_{i=1}^{n} \frac{N_{i}}{\sqrt{2 \pi} \log \left(o_{g, i}\right)} \exp \left[-\frac{\left(\log \left(D_{p}\right)-\log \left(\bar{D}_{p g, i}\right)\right)^{2}}{2 \log ^{2}\left(o_{g, i}\right)}\right]
\end{aligned}
$$

where $D_{p}[\mathrm{~nm}]$ is the particle diameter, and the three parameters that characterize an individual mode $i$ are: the total number concentration $N_{i}\left[\mathrm{~cm}^{-3}\right]$, the geometrical variance $\sigma_{g, i}^{2}\left[\mathrm{~nm}^{2}\right]$, and the geometrical mean diameter $D_{p g, i}(\mathrm{~nm})$. $n$ is the number of possible individual modes. We will recall these parameters in this study without the subscript " $i$ "; i.e. $N, D_{p g}$, and $\sigma_{g}$. In some places of this study, we will use GMD instead of the geometric mean particle diameter or $D_{p g}$.

\subsection{Weather conditions in Helsinki during 1997-2002}

The weather conditions (temperature, pressure, and wind speed and direction) were available from the Finnish Meteorological Institute (FMI) in Helsinki. Throughout the five years (1997-2002), the daily mean pressure varied between 980 and $1040 \mathrm{hPa}$. The coldest period was during January and February. The mean wind direction was southwesterly and the daily mean wind speed was lower than $9 \mathrm{~m} / \mathrm{s}$. The daily mean temperature varied between -10 and $25^{\circ} \mathrm{C}$; seldom was lower than $-10^{\circ} \mathrm{C}$ observed in the wintertime.

An annual periodicity was observed in the daily mean temperature, which was best fit to the periodic function

$T(d)=280.35+12.0 \cdot \sin \left[2 \pi \frac{d}{366}+\frac{4}{3} \pi\right]$

where $T$ [Kelven] is the daily mean temperature and $d$ is the day number starting by 1 for 1 January 1997.

\subsubsection{Seasonal periods in Helsinki according to the temper- ature variation}

According to the temperature variation, the seasons are defined by the daily mean temperature. However, with this method the length of different seasons might vary considerably from year to year. In the southern part of Finland, winter usually begins during November and ends by late March. Spring starts in early or mid April and ends in mid May, when summer usually begins and lasts until mid September. Autumn begins around the last week of September. Detailed information about the weather changes and climate can be found from the web page of the Finnish Meteorological Institute http://www.fmi.fi/weather/climate_4.html.

In summary, the thermal seasonal periods can be called for short as NDJFM, A(M), (M)JJAS, and SO respectively for winter, spring, summer, and autumn. We put "(M)" to indicate that the season starts/ends in mid May.

\subsection{Traffic density in Helsinki metropolitan area during 1997-2002}

Traffic density in Helsinki showed slightly increasing trend between 1997 and 2001. The annual increase was about 2\% on average (Lilleberg and Hellman, 2003). In the year 2002 the traffic density in Helsinki decreased about $3 \%$. The mean constitution of all vehicles in the city center during 2000 2002 was: passenger cars $81 \%$, vans $10 \%$, trucks $3 \%$ and buses $6 \%$. When moving away from the city center towards the city border the amount of passenger cars was $83 \%$, vans $9 \%$, trucks $6 \%$ and buses $2 \%$.

\subsubsection{Traffic density during workdays (Monday-Friday)}

The daily mean (1997-2002) traffic density of all vehicles varied between 463,000 and 525,000 vehicle/day during September on the outer motorways inside the Helsinki 
Table 1. GM's of the fitting parameters of each mode.

\begin{tabular}{|c|c|c|c|c|c|c|c|}
\hline & & \multicolumn{3}{|c|}{ Siltavuori } & \multicolumn{3}{|c|}{ Kumpula } \\
\hline & & $\sigma \mathrm{g}$ & $D_{p g}[\mathrm{~nm}]$ & $N\left[\mathrm{~cm}^{-3}\right]$ & $\sigma \mathrm{g}$ & $D_{p g}[\mathrm{~nm}]$ & $N\left[\mathrm{~cm}^{-3}\right]$ \\
\hline \multirow[t]{3}{*}{ Nucleation mode } & Mode 1 & 1.71 & 11.7 & 7100 & 1.63 & 13.8 & 5670 \\
\hline & Mode 1a (fresh mode) & - & - & - & - & 8.9 & - \\
\hline & Mode $1 \mathrm{~b}$ & - & 11.7 & - & - & 17.7 & - \\
\hline \multirow[t]{3}{*}{ Aitken mode } & Mode 2 & 1.78 & 37.3 & 6320 & 1.71 & 42.5 & 4050 \\
\hline & Mode 2a (Extra mode) & - & 25.9 & - & - & 24.4 & - \\
\hline & Mode $2 b$ & - & 43.8 & - & - & 48.1 & - \\
\hline Accumulation mode & Mode 3 & 1.60 & 150.5 & 960 & 1.54 & 151.8 & 900 \\
\hline
\end{tabular}

metropolitan. The daily mean traffic density in the city center varied between 360,000 and 260,000 vehicle/day. Among the workdays, the traffic density was highest during Wednesday through Friday. Among the months, the traffic density was highest during May and June and lowest during July (summer holiday), right after Christmas, and February (ski holidays).

Among the day, the traffic density was lowest during the late night time (after 22:00) and early morning (before 04:30). The highest traffic activity was during the morning (05:00-09:00) and afternoon (13.00-17:00) rush hours. During the late morning and midday (09:00-13:00), the traffic activity was approximately half its value during the rush hours.

2.5.2 Traffic density during weekend (Saturday and Sunday)

The traffic density during the weekend was lower than that during workdays. The traffic density during weekends was higher in the city center than on the outer motorways inside the Helsinki metropolitan. The main differences in traffic density between workdays and weekends were: (1) the traffic density was higher than the weekly average during workdays and lower during weekends, (2) the traffic density decreased towards city center during workdays while it increased towards city center during weekends, and (3) the daily pattern of the traffic density during workdays consisted of two peaks (morning and afternoon rush hours), while the daily pattern during weekend days consisted of a wide shallow peak (see Fig. 2).

\section{Results and discussion}

\subsection{Particle number size distributions}

Multi-lognormal fitting was performed on the half-hourly means of the number size distribution. About $18 \%$ of the fitting cases required either two or more than three modes to best fit the number size distribution. The requirement of more than three modes was due to the very dynamistic feature of urban aerosols. In urban conditions, the particle size distributions vary rapidly in shape and magnitude following the instantaneous traffic variation and local meteorology. Therefore, running half-hour means, which may include six measured instantaneous number size distributions, sometimes produce artificial mean number size distributions that may consist of more three modes of aerosol particles.

The analysis with respect to the mode GMD showed the existence of three main characteristic modes: mode 1 (nucleation mode) that existed within particle diameter smaller than $30 \mathrm{~nm}$, mode 2 (Aitken mode) within 20-100 nm, and mode 3 (accumulation mode) within particles larger than $90 \mathrm{~nm}$. The GMD of the accumulation mode was not observed within particle diameters larger than $350 \mathrm{~nm}$. The frequency histograms of the mode GMD are presented in Fig. 3, and mean values are shown in Table 1. The monthly GM and GSD values of the $D_{p g}, \sigma_{g}$, and $N$ are presented in Appendix A. The geometric mean of the $\sigma_{g}$ was about $1.71,1.78$, and 1.60 respectively for the nucleation mode, Aitken mode, and accumulation mode at Siltavuori, and about 1.63, 1.71, and 1.54 for the same order at Kumpula.

As can be seen from Fig. 3, the nucleation mode consisted of two submodes at Kumpula and one mode at Siltavuori. The nucleation submode 1 (Mode 1a; fresh mode) existed with a GMD of $8.9 \mathrm{~nm}$ at Kumpula. The corresponding Mode 1a at Siltavuori was not observed because it is smaller than the measured particle size range. This nucleation submode represented the fresh nucleation mode, which is produced by direct traffic emissions and gas to particle conversion. The nucleation submode 2 (Mode 1b) existed with a GMD of about $11.7 \mathrm{~nm}$ at Siltavuori and $17.7 \mathrm{~nm}$ at Kumpula.

The GMD of the Aitken mode (Mode 2b) was about $43.8 \mathrm{~nm}$ at Siltavuori and $48.1 \mathrm{~nm}$ at Kumpula. An extra mode (Mode 2a, extra mode) was observed with a GMD of about $25 \mathrm{~nm}$. The accumulation mode GMD was about $150 \mathrm{~nm}$ at both sites. The extra mode (Mode 2a) is believed to be of a regional origin because it existed with an equal percentage (about $25 \%$ of Mode 2) at both sites. The accumulation mode was also observed with similar characteristics at both sites, which is an indication of a regional characteristic in this mode. 

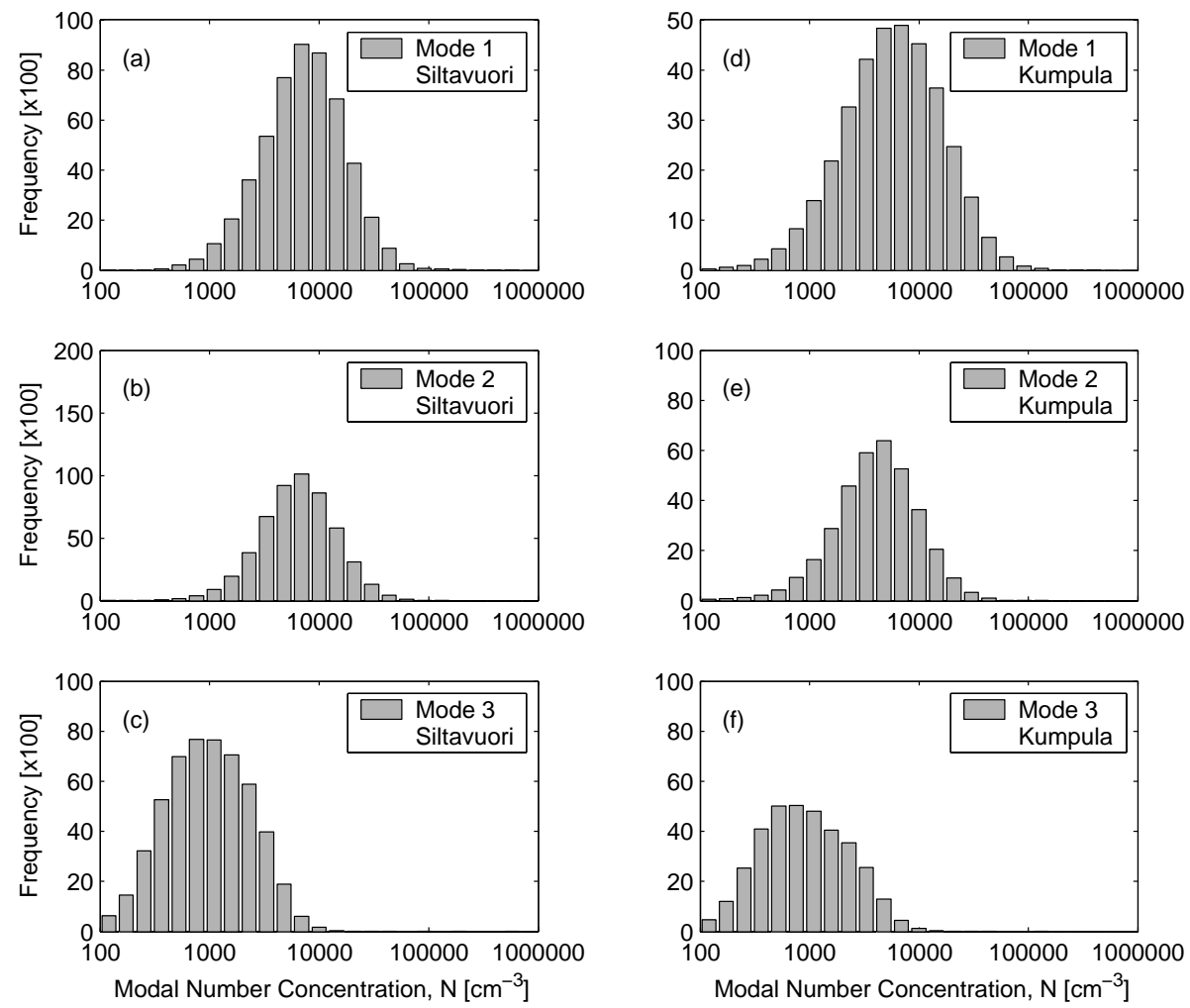

Fig. 5. Frequency histograms of the mode number concentrations $\left(\mathrm{N}_{i}\right)$ at Siltavuori (a)-(c) and at Kumpula (d)-(f).

Table 2. Annual means and medians of the total number concentrations $\left[\mathrm{cm}^{-3}\right.$ ]. From 1 January 1998 to 5 March 2001 the measurement was at Siltavuori, and after that it has been at Kumpula.

\begin{tabular}{cccc}
\hline Year & Median & Geometric mean & Arithmetic mean \\
\hline 1998 & 12993 & 13819 & 17590 \\
1999 & 13587 & 14265 & 17812 \\
2000 & 13042 & 13313 & 16450 \\
2001 & 11418 & 12230 & 16093 \\
2002 & 9553 & 10077 & 13588 \\
\hline
\end{tabular}

The GMD at Kumpula were larger than those at Siltavuori, which was due to the evolution of the aerosol particles while transported from its origin; i.e. the ultrafine particles $\left(D_{p}<100 \mathrm{~nm}\right)$ at Kumpula were a bit older than those at Siltavuori and their GMD values were shifted to larger particle diameters. Another reason for the difference in the GMD values between both sites is the building constructions that took place nearby the measurement site at Kumpula. In Fig. 4 we see clearly, the changes in the GMD values of the nucleation and Aitken modes at Kumpula during the construction of a new building nearby the measurement site. This was particularly clear during the intensive rock blasting, which produced higher concentrations of big particles causing a higher coagulation sink to eat up smaller particles in nucleation mode and also hindering formation of new particles (see e.g. Kulmala et al., 2001).

On the other hand, the landscape and measurement elevations played a role in the GMD shift. Siltavuori was an open area directly exposed to the traffic emissions from the downtown area from the northern side and densely office and apartment buildings with many roads and streets from the southern side. The northern side of Kumpula was mainly park fields that were partly covered with trees, while a dense tree strip (about $200 \mathrm{~m}$ width) separated between the physics department building at Kumpula from the main highway on the southern side. Also, the measurements at Kumpula were held at the fourth floor level (about $15 \mathrm{~m}$ ) above the ground level. Recently formed ultrafine particles may grow by condensation and coagulation resulting in a shift of the maximum diameter of the number size distribution (Kulmala et al., 2004; Wehner et al., 2002; Wu et al., 2002; Zhang and Wexler, 2002). Therefore, during transport from the street portion to the urban background, several processes may influence the number size distributions, such as coagulation, condensational growth, plume dilution, and vertical mixing (Turco and Fangqun, 1999). However, the building construction nearby will produce a large amount of dust and coarse particles increasing the coagulation sink and reduce the number concentration of smaller particles; especially ultrafine particles (Jung et al., 2002). 

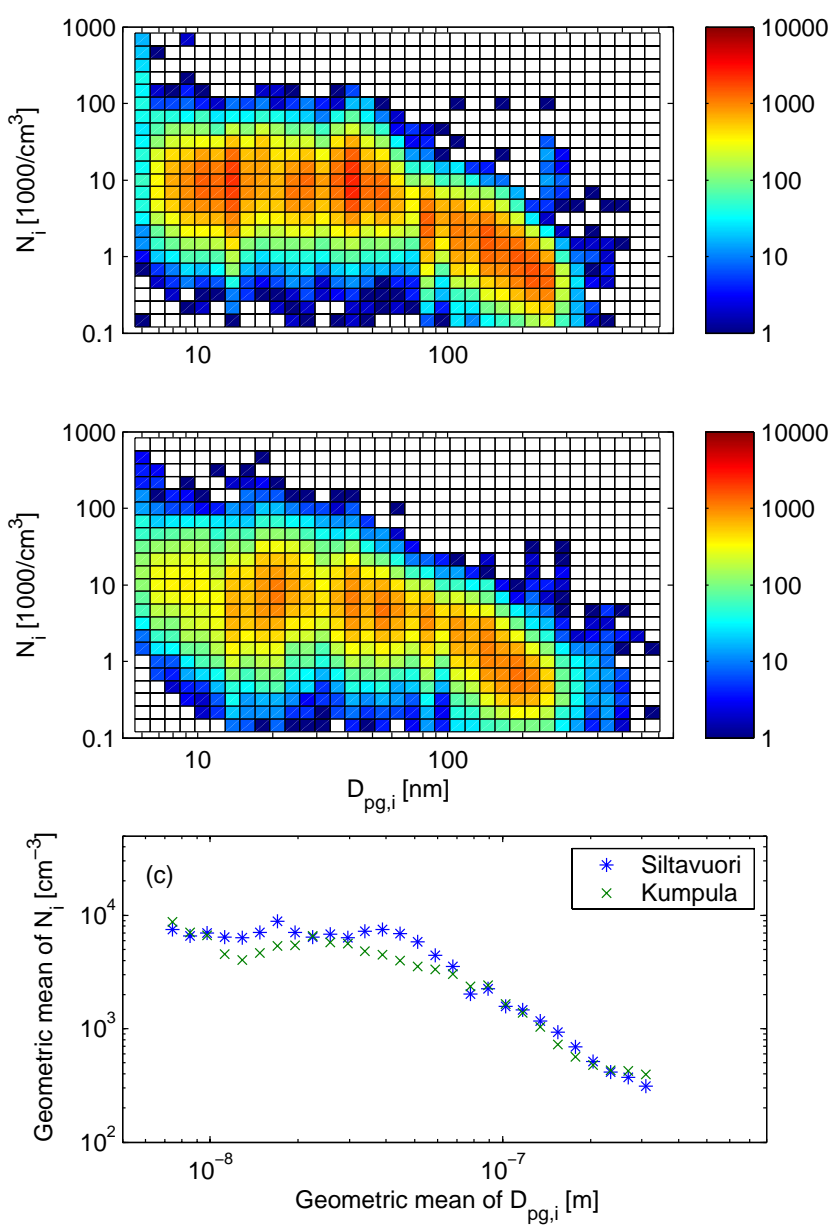

Fig. 6. Frequency histograms within a certain modal concentration range $\left(N_{i}\right)$ and a modal geometric mean diameter range $\left(D_{p g, i}\right)$ (a) at Siltavuori and (b) Kumpula. (c) The geometric mean of $\left(N_{i}\right)$ versus the geometric mean of the geometric mean diameter $\left(D_{p g}\right)$.

The mode number concentration showed lognormal characteristics (Fig. 5). The geometric mean of the mode number concentrations were about $7000 \mathrm{~cm}^{-3}, 6500 \mathrm{~cm}^{-3}$, and $1000 \mathrm{~cm}^{-3}$ respectively for the nucleation mode (Mode 1), Aitken mode (Mode 2), and the accumulation mode (Mode 3) at Siltavuori, and about $5500 \mathrm{~cm}^{-3}, 4000 \mathrm{~cm}^{-3}$, and $1000 \mathrm{~cm}^{-3}$ at Kumpula respectively for the same order. The mode number concentration variation with respect to its GMD showed relatively similar characteristics at both sites (Fig. 6). The largest number concentrations were observed for modes with GMD smaller than $100 \mathrm{~nm}$. The mode number concentration within the accumulation mode (Mode 3) decreased when the GMD increased. Some differences between the two sites were observed. The mode number concentration was about $2000 \mathrm{~cm}^{-3}$ higher at Siltavuori than at Kumpula within the GMD ranges $10-20 \mathrm{~nm}$ and $30-60 \mathrm{~nm}$ (Fig. 6c). There was also a slight difference within the GMD range $150-200 \mathrm{~nm}$ (Fig. 6c). The smaller concentrations at Kumpula were mainly due to the slight decreasing trend during the latest years.

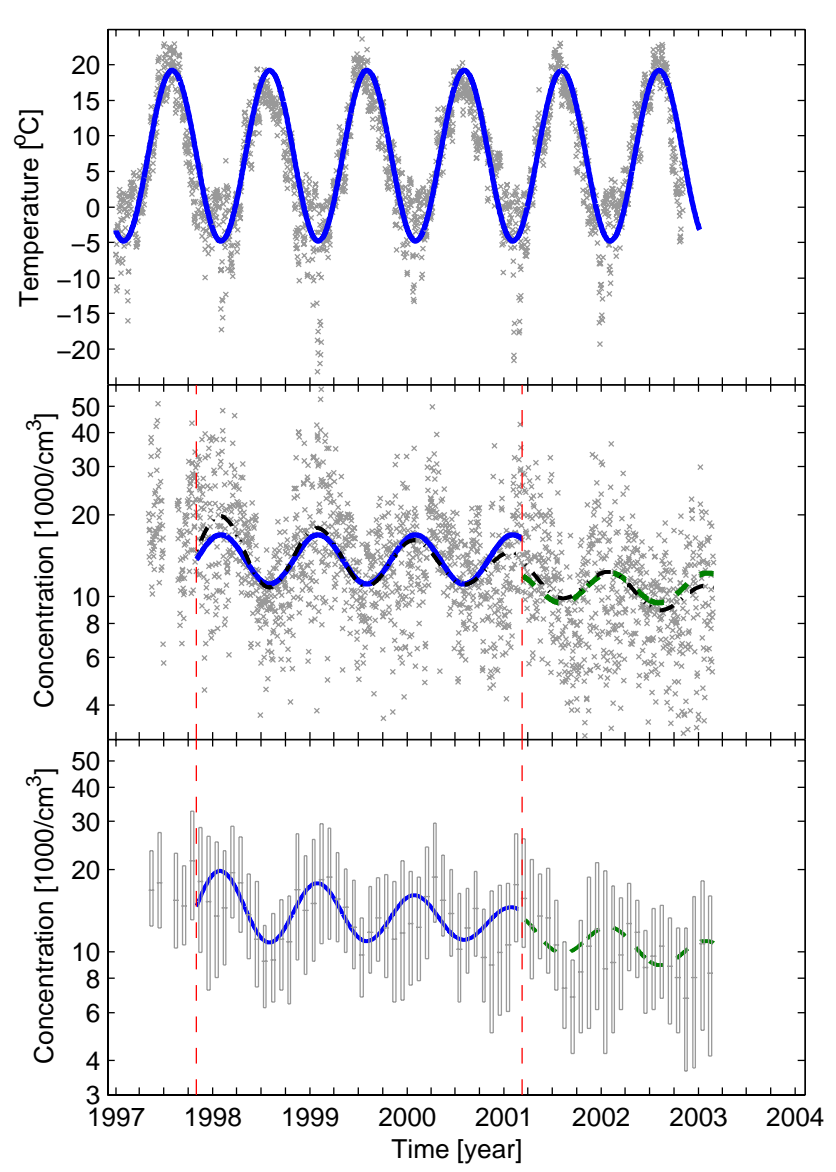

Fig. 7. (a) Temporal variation of the temperature. Temporal variation of the total number concentration $\left(8 \mathrm{~nm}<D_{p}<400 \mathrm{~nm}\right)$ presented as (b) daily medians and (c) monthly medians (with $25 \%$ as the lower limit of the box plot and $75 \%$ as the upper limit).

\subsection{Total number concentrations}

Monthly arithmetic mean, standard deviation, and medians with different percentiles $(5 \%, 25 \%, 75 \%$, and 95\%) of the total number concentrations were evaluated from the hourly medians (Appendix B). The minimum 30-minute value was around $1000 \mathrm{~cm}^{-3}$ and the maximum was around $60000 \mathrm{~cm}^{-3}$. The monthly total number concentrations showed a decreasing trend accompanied by a periodic behavior. This was observed at both Siltavuori and Kumpula (Fig. 7).

On the annual basis (Table 2), the geometric mean value of the total number concentrations increased by about $3 \%$ in year 1999 , and then decreased by $7 \%$ in year 2000 . The decreasing trend in the total number concentration continued in the following years to be about $17 \%$ in year 2002 . The annual variation in the number concentration was clearly related to the traffic density and vehicle engine type as well as the new technology used in engine performance. In Helsinki, 
Table 3. Multi-lognormal fitting parameters of the mean number size distributions during different seasons.

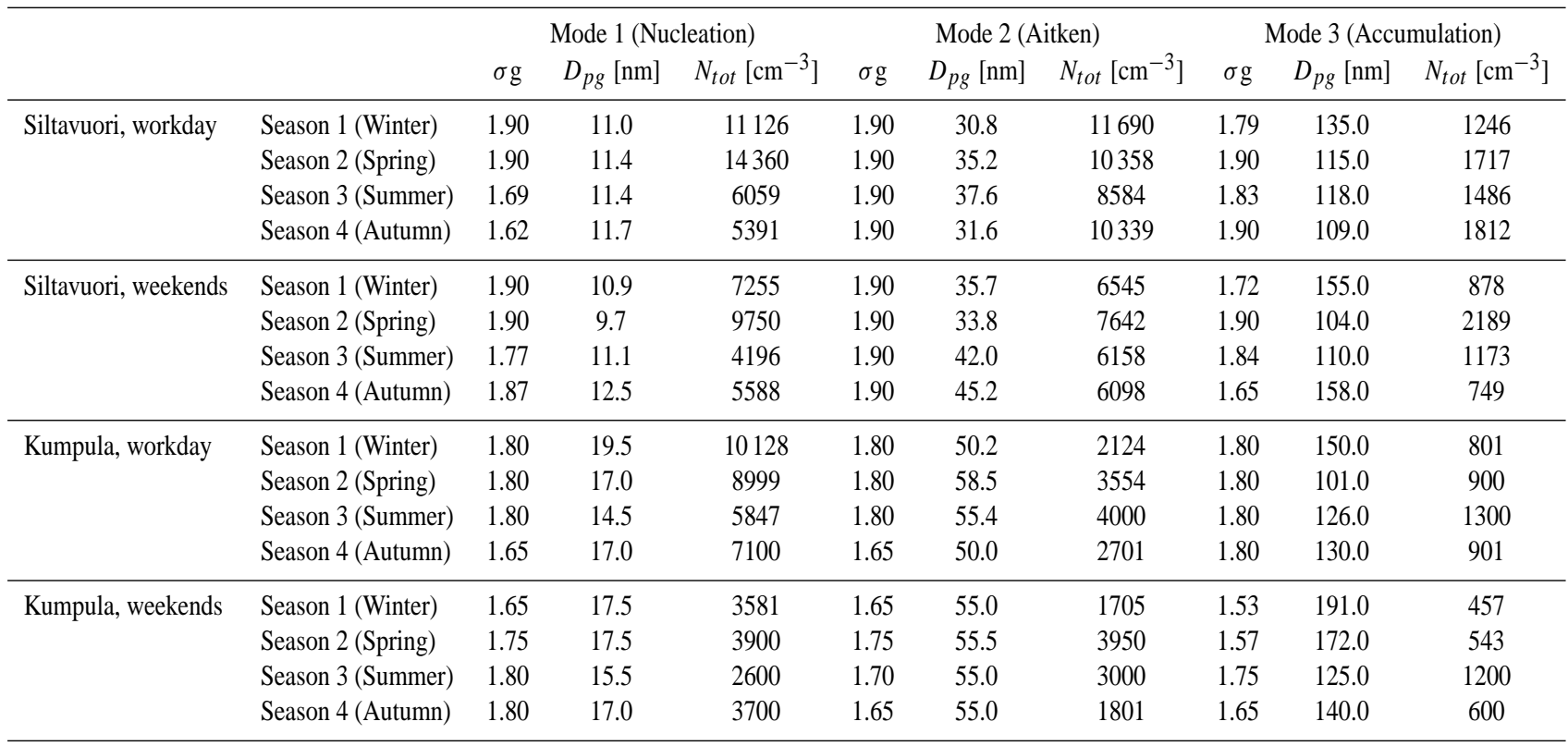

the cars have been renewed continuously, and because new cars are less harmful to environment due to their engine type, this would lead to a decrease in the pollutants due to traffic combustion.

A characteristic periodic behavior was observed in the daily mean total number concentration (Fig. 7). The total number concentration was higher during the wintertime and lower during the summertime. A periodic function was used to fit the total number concentrations daily medians. At Siltavuori the periodic variation was best represented by

$\log _{10}\left[\frac{N_{\text {tot }}(d)}{1 \mathrm{~cm}^{-3}}\right]=4.1369-0.0903 \cdot \sin \left[2 \pi \frac{d}{366}+\frac{4}{3} \pi\right](5)$

and for that at Kumpula

$\log _{10}\left[\frac{N_{\text {tot }}(d)}{1 \mathrm{~cm}^{-3}}\right]=4.0323-0.0547 \cdot \sin \left[2 \pi \frac{d}{366}+\frac{4}{3} \pi\right](6)$

where $N_{\text {tot }}\left[\mathrm{cm}^{-3}\right]$ is the daily median total number concentration, $d$ is the day number starting by 1 for 1 January 1997 .

It was difficult to observe the weekly pattern in the total number concentrations, because the temporal variation of the total number concentrations was larger than the weekly variation. Therefore, the annual variation had the strongest signal in the analysis. Clearly, the annual periodic behavior of the total number concentration was inversely related to that of the temperature, which was represented by a sinusoidal function of the same period but they were out of phase $\left(180^{\circ}\right)$.

\subsection{Seasonal variation}

The aerosol particle characteristics (modal structure and temporal variation) showed distinct differences during different times in the year. This represented the seasonal variation of the aerosol particles in Helsinki. The first period was 1 November-28 February (NDJF), which was called Season 1 , with lower total number concentrations during November and higher concentrations during February. The second period (Season 2) was 1 March-31 May (MAM) followed by Season 31 June-15 August (JJ"A") and then Season 4 15 August-31 October ("A"SO). The thermal seasons were defined in a slightly different way. In the thermal seasons, the seasons are defined according to the daily mean temperature variation during the year, which was in the Helsinki area following the order NDJFM, A(M), (M)JJAS, and SO. In our present study the seasons were chosen according to the change in the aerosol characteristics (daily pattern and modal structure).

Figure 8 presents median particle number size distributions within selected hours during workdays, and those during weekends are presented in Fig. 9. The background particle number size distributions were observed during the early hours of the day (between 01:00 and 04:00) regardless of whether it was a workday or weekend. During these hours, the number concentrations of the nucleation and Aitken modes were the lowest. During different hours of the day, the particle number distributions exhibited different characteristics. These characteristics were directly related to the traffic activity in Helsinki. For example, the high concentrations of the ultrafine particles were observed during the traffic rush hours, whether it was a workday or at weekends. The concentrations were significantly lower during weekends than workdays, which are also correlated to lower traffic activity during weekends. As can be seen from Figs. 8 and 9, 


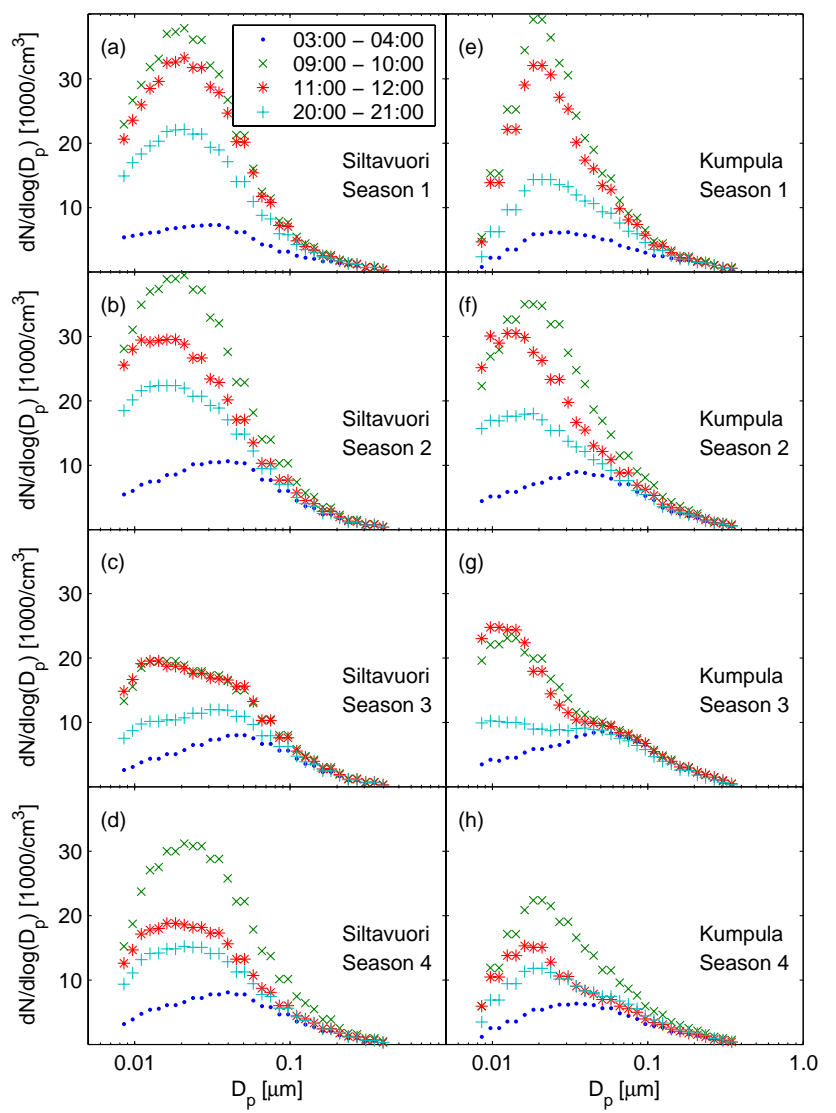

Fig. 8. Particle number size distributions during different hours of the workdays and also seasons. (a)-(d) Siltavuori and (e)-(h) Kumpula.

the difference in the particle number size distributions during different hours of the day is less during the Season 3 than other seasons. For example, the size distributions were closely similar at all times of the weekend during Season 3 (Fig. 9c and g).

Laboratory test have shown diesel engine combustion signature to be lognormal with mean diameters ranging from 60 to $120 \mathrm{~nm}$, whereas those from a gasoline engine exhaust tend to have smaller mean diameters ranging from 40 to $80 \mathrm{~nm}$ (Harris and Maricq, 2001). The strongest signal of the traffic emissions was observed during the workdays' morning traffic rush hours. During midday hours, the traffic signal was weaker, because of lower traffic density during those hours. In the late evening hours, the nucleation mode and Aitken mode particles seemed to be dispersed and vanished to retain the background number size distributions. During weekend's at daytime, the signal from traffic combustion was observed during midday hours and afternoon, but with lower number concentrations compared to workdays (Fig. 9).

The median particle number size distributions were averaged during the different seasons at Siltavuori and Kumpula (Fig. 10). The mean number size distributions were then

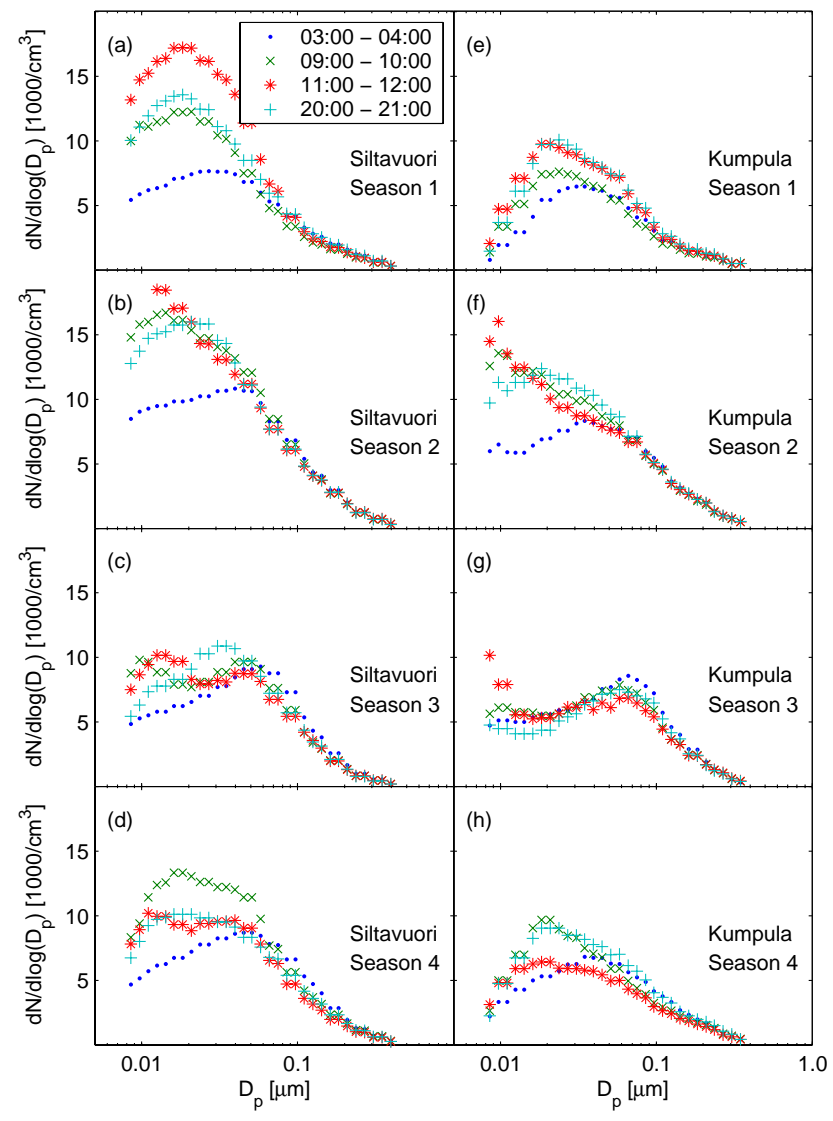

Fig. 9. Particle number size distributions during different hours of the weekends and also seasons. (a)-(d) Siltavuori and ((e)-(h) Kumpula.

fitted to the multi-lognormal function described in equation (3). The modal parameters $D_{p g, i}, \sigma_{g, i}$, and $N_{i}$ of the seasonal particle number size distributions are presented in Table 3. As postulated previously in this study, the differences in the particle number distribution characteristics between Siltavuori and Kumpula were clear in the GMD shift to larger values at Kumpula, and higher ultrafine concentrations at Siltavuori.

The daily patterns of aerosol concentrations showed a direct relationship with the traffic density. The total number concentrations had higher values during the day time; from 05:00 to 18:00 on workdays and 07:00-20:00 on weekends. On a seasonal basis, the aerosol daily patterns showed different characteristic patterns in different seasons (Figs. 11 and 12). The daily variation in the accumulation mode particles was not significant. The variation was larger in the ultrafine particles; especially nucleation mode particles. Table 4 presents mean total particle number concentrations during different hours of the day and season.

On workdays (Fig. 11), the daily pattern of aerosols during Season 1 was characterized by two peaks (maximum at 09:00 and minimum at 03:00) representing the traffic rush 


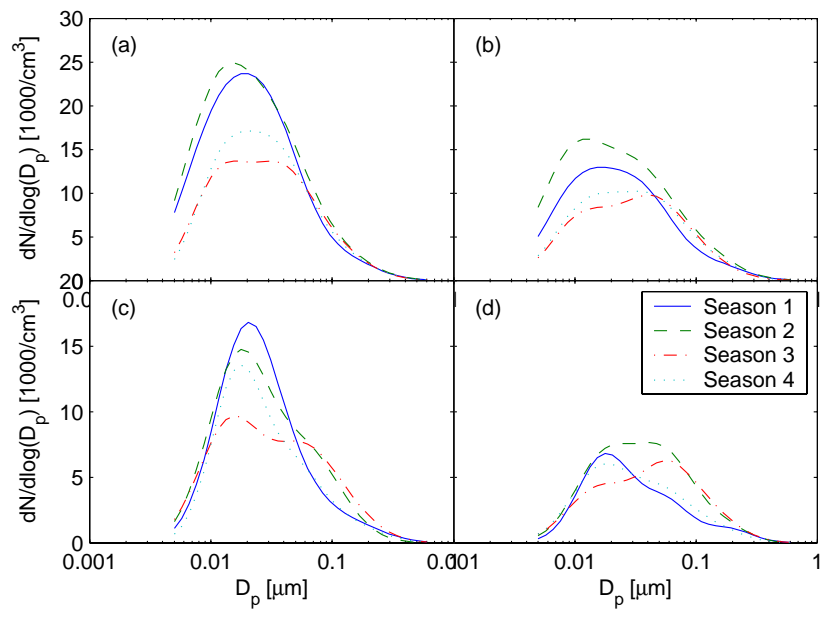

Fig. 10. Seasonal number size distributions at Siltavuori during (a) workdays and (b) weekends. (c) and (d) are the same but for Kumpula.

hours. The morning peak became larger during Season 2 and then. Both peaks were reduced during Season 3, and then in Season 4, the first peak was very clear with higher concentrations. On weekends (Fig. 12), the daily pattern of aerosols was characterized by a wide peak (maximum between 12:00 and 18:00 and minimum at 06:00) that dominated the daytime. The peak became wider with lower concentrations during season 2. Then the wide peak was not clear during Season 3 (the total number concentration at both sites did not exceed $10000 \mathrm{~cm}^{-3}$ ), when the number concentrations stayed relatively constant (Fig. 12c and g).

\section{Summary and Conclusions}

Long-term and continuous aerosol particle number size distribution measurements were performed in Helsinki, Finland since 5 May 1997. The aerosol data until 28 February 2003 was analyzed. The measurements were performed at Siltavuori during 1997-2001. After March 2001, the measurement site was at Kumpula. The temporal, diurnal, seasonal and annual variations of particle size distributions and total number concentrations were investigated. Investigations of long-term aerosol data sets are not sensitive to uncommon weather or emission conditions like campaign type observations.

In the Helsinki urban area, over $80 \%$ of the number size distributions consisted of three modes: nucleation mode $\left(D_{p}<30 \mathrm{~nm}\right)$, Aitken mode $(20-100 \mathrm{~nm})$ and accumulation mode $\left(D_{p}>90 \mathrm{~nm}\right)$. Less than $20 \%$ of the number size distributions either consisted of two modes or four modes. At Siltavuori, the modal GMD values were $11.7 \mathrm{~nm}$ for nucleation mode, $37.3 \mathrm{~nm}$ for Aitken mode and $150.5 \mathrm{~nm}$ for accumulation mode. The mode GMD values at Kumpula were $13.8 \mathrm{~nm}$ for nucleation, $42.5 \mathrm{~nm}$ for Aitken and $151.8 \mathrm{~nm}$ for accumu-
Table 4. Mean total particle number concentration $\left[\mathrm{cm}^{-3}\right]$ during different hours of the day and seasons.

\begin{tabular}{|c|c|c|c|c|}
\hline & & & Siltavuori & Kumpula \\
\hline \multirow[t]{20}{*}{ Workdays } & \multirow[t]{5}{*}{ Season 1} & 01:00 & 7500 & 5000 \\
\hline & & 03:00 (minimum) & 5000 & 4000 \\
\hline & & Morning (maximum) & 25000 & 22000 \\
\hline & & Afternoon (maximum) & 23000 & 15000 \\
\hline & & Midnight & 10000 & 6000 \\
\hline & \multirow[t]{5}{*}{ Season 2} & 01:00 & 10000 & 9000 \\
\hline & & 03:00 (minimum) & 9000 & 7500 \\
\hline & & Morning (maximum) & 30000 & 28000 \\
\hline & & Afternoon (maximum) & 21000 & 17500 \\
\hline & & Midnight & 12500 & 10000 \\
\hline & \multirow[t]{5}{*}{ Season 3} & 01:00 & 7500 & 8000 \\
\hline & & 03:00 (minimum) & 6000 & 7500 \\
\hline & & Morning (maximum) & 17500 & 20000 \\
\hline & & Afternoon (maximum) & 15000 & 15000 \\
\hline & & Midnight & 8000 & 8000 \\
\hline & \multirow[t]{5}{*}{ Season 4} & 01:00 & 7500 & 6000 \\
\hline & & 03:00 (minimum) & 7500 & 5000 \\
\hline & & Morning (maximum) & 25000 & 17500 \\
\hline & & Afternoon (maximum) & 15000 & 10000 \\
\hline & & Midnight & 8000 & 6000 \\
\hline \multirow[t]{16}{*}{ Weekends } & \multirow[t]{4}{*}{ Season 1} & 01:00 & 8000 & 5000 \\
\hline & & 06:00 (minimum) & 5000 & 3500 \\
\hline & & 12:00-18:00 (maximum) & 12500 & 10000 \\
\hline & & Midnight & 7500 & 4000 \\
\hline & \multirow[t]{4}{*}{ Season 2} & 01:00 & 12000 & 10000 \\
\hline & & 06:00 (minimum) & 10000 & 7500 \\
\hline & & 12:00-18:00 (maximum) & 14000 & 10000 \\
\hline & & Midnight & 12000 & 10000 \\
\hline & \multirow[t]{4}{*}{ Season 3} & 01:00 & 8000 & 8000 \\
\hline & & 06:00 (minimum) & 7000 & 6000 \\
\hline & & 12:00-18:00 (maximum) & 8000 & 6000 \\
\hline & & Midnight & 9000 & 9000 \\
\hline & \multirow[t]{4}{*}{ Season 4} & 01:00 & 9000 & 6000 \\
\hline & & 06:00 (minimum) & 7000 & 5000 \\
\hline & & 12:00-18:00 (maximum) & 7500 & 6000 \\
\hline & & Midnight & 8000 & 7000 \\
\hline
\end{tabular}

lation modes. The fresh nucleation mode was observed at Kumpula with a GMD $8.9 \mathrm{~nm}$. This mode was not observed at Siltavuori because it was smaller than the measured size range. The GMD of the aged nucleation mode was $13.8 \mathrm{~nm}$ at Siltavuori and $17.7 \mathrm{~nm}$ at Kumpula. There was also a young Aitken mode (extra mode) that was observed with $25 \mathrm{~nm}$ a GMD at both sites. The aged Aitken mode was observed at GMD $43.8 \mathrm{~nm}$ at Siltavuori and $48.1 \mathrm{~nm}$ at Kumpula.

In other European cites, the fresh mode was observed at $5.9 \mathrm{~nm}$ GMD, and the aged nucleation mode was seen at $15.8 \mathrm{~nm}$ (Birmili et al., 2001). In the same study, the Aitken 


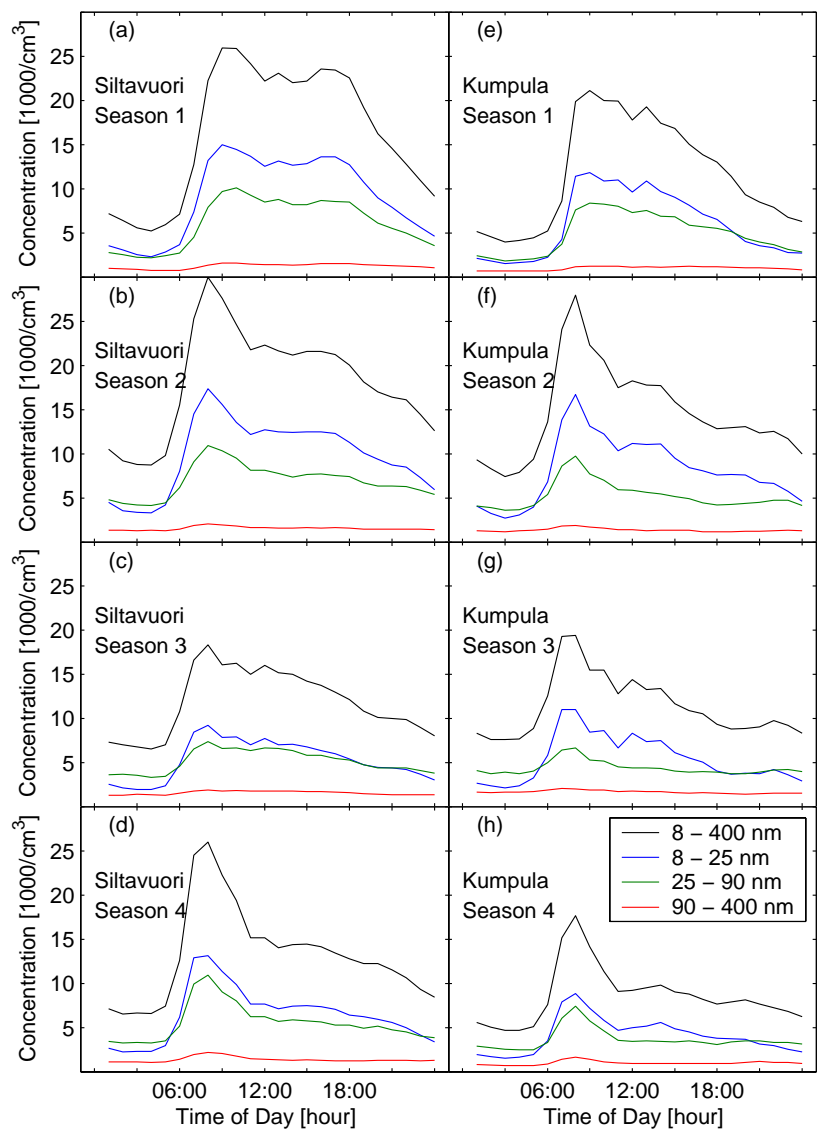

Fig. 11. Daily patterns of the total number concentration on workdays during the different seasons. (a)-(d) Siltavuori and (e)-(h) Kumpula.

mode GMD ranged between $58 \mathrm{~nm}$ and $76 \mathrm{~nm}$ depending on the air mass origin, and the accumulation mode existed with larger GMD ranging from $187 \mathrm{~nm}$ to $218 \mathrm{~nm}$ (Birmili et al., 2001). An even larger GMD for the accumulation mode was observed in Leipzig-Germany (Wehner and Wiedensohler, 2003). Wehner and Wiedensohler (2003) have shown that the nucleation mode GMD existed within $11 \mathrm{~nm}$ and $18 \mathrm{~nm}$, whereas for the Aitken mode it was between $39 \mathrm{~nm}$ and $68 \mathrm{~nm}$.

The small GMD of the Aitken mode observed at Helsinki seems to be characteristic of Scandinavian conditions. Tunved et al. (2003) have shown that two Aitken modes existed in five background locations spread out from south to north Scandinavia. For north-east air masses, the first Aitken mode had a GMD ranging from $30 \mathrm{~nm}$ and $40 \mathrm{~nm}$, whereas the second Aitken mode $40 \mathrm{~nm}$ to $55 \mathrm{~nm}$. These values stay more comparable to what we have found at Helsinki. Furthermore, the nucleation mode observed by Tunved et al. (2003) was also in the same range of the aged nucleation mode observed at Helsinki. But the accumulation mode GMD was larger than $165 \mathrm{~nm}$ in the background areas in

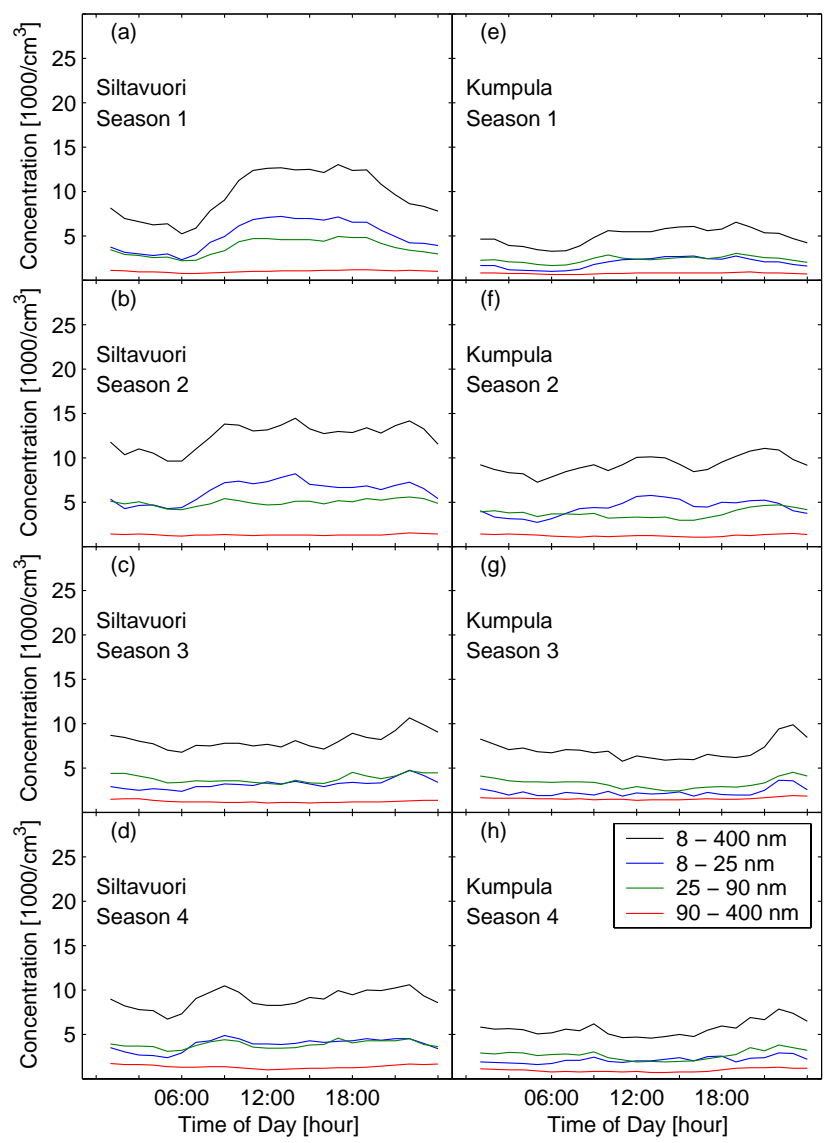

Fig. 12. Daily patterns of the total number concentration on weekends during the different seasons. (a)-(d) Siltavuori and (e)-(h) Kumpula.

Scandinavia compared to what we have observed at Helsinki $(\mathrm{GMD} \sim 150 \mathrm{~nm})$. However, when the air mass originated from south-west, the GMD values of all the modes were shifted to larger values that coincide with the characteristics observed by Birmili et al. (2001) and Wehner and Wiednesohler (2003).

The arithmetic mean values of the mode number concentrations observed at Siltavuori were about $7000 \mathrm{~cm}^{-3}$, $6500 \mathrm{~cm}^{-3}$ and $1000 \mathrm{~cm}^{-3}$ respectively for nucleation, Aitken and accumulation modes. At Kumpula they were about $5500 \mathrm{~cm}^{-3}, 4000 \mathrm{~cm}^{-3}$ and $1000 \mathrm{~cm}^{-3}$. The difference between the two sites was mainly due to the fact that at Kumpula the building constructions in the vicinity produced big particles (like building dust) caused a large coagulation sink to eat up a significant fraction of the ultrafine particles and a large condensation sink to prevent new particle formation. On the other hand, the larger GMD values at Kumpula were due to the evolution of the aerosol particles during transportation from their origin; i.e. the ultrafine particles $\left(d_{p}<100 \mathrm{~nm}\right)$ at Kumpula were a bit older than those at Siltavuori. 
The total number concentrations in the nucleation and Aitken modes were significantly higher on workdays than weekends. The difference in accumulation mode was not significant. At Siltavuori and Kumpula, the temporal variation of the total number concentrations and ultrafine particle concentrations followed closely the traffic density variation. Among the workdays, the highest concentrations were observed on Fridays, and among weekends the lowest concentrations were observed on Sundays. Seasonally, the lowest total number concentrations were observed during summerholiday months (June-July) and the highest total number concentrations during March-April. This was also because of lower traffic density during summer holidays in Helsinki. Also the peak numbers concentrations occurred during rush hours.

The total number concentration observed in Helsinki seems to be lower than what can be found in other urban conditions in the European countries. For example, Wehner and Wiendensohler (2003) have shown that during the night, the mean total number concentration was about $23500 \mathrm{~cm}^{-3}$ during the winter workdays and about $16200 \mathrm{~cm}^{-3}$ during the summer workdays. However, the daily patterns seemed to be similar in Leipzig and Helsinki.

Within Finland (Laakso et al., 2003), the total number concentration was about the $2000 \mathrm{~cm}^{-3}$ in a background location (Hyytiälä) in southern Finland, and it was about $1000 \mathrm{~cm}^{-3}$ in the background conditions in the northern part of Finland (Värriö and Pallas). The daily patterns of the total number concentrations were clearly negligible at these background stations. The daily patterns of $\mathrm{PM}_{10}$ concentrations at a background station in the Helsinki out skirts was less than $15 \mu \mathrm{g} / \mathrm{m}^{3}$ with a minimum less than $10 \mu \mathrm{m} / \mathrm{m}^{3}$ at noon and a maximum at midnight, whereas at Siltavuori, the daily pattern of the PM10 showed similar variation as those observed for the total number concentrations (Laakso et al., 2003).

An understanding of the particle size distributions provides more information on the type of atmospheric processes resulting in aerosols. The modal structure of the particle size distribution is one such aspect that has been associated with aerosol formation mechanisms (e.g. Mäkelä et al., 1997). Knowledge and understanding of the presence and location of modes in particle size distributions is of importance not only for understanding the mechanisms of atmospheric processes, but also, for exposure and risk assessment. Complex size distributions of airborne particles in ambient air result from a multiplicity of sources generating particles of different composition as well as of different size and concentration characteristics.

In order to be able to study urban aerosol dynamics and the possible health effects of aerosol particles long continuous data sets are needed. The present data is a good example of this kind of data set, which can be used for different purposes, e.g. the observed $95 \%$ value of number concentration can be used when new air quality directives are considered. On the other hand the effect of traffic density and building construction can be seen and the local air quality information can be given according to known activities. In addition, urban air quality models can be tested against representative continuous data sets. 


\section{Appendix A}

Monthly GM \pm GSD of the modal $D_{p g}, \sigma_{p g}$, and $N$

\begin{tabular}{cccccccccc}
\hline 1997 & & $\begin{array}{c}D_{p g}[\mathrm{~nm}] \\
\text { Mode 2 }\end{array}$ & Mode 3 & Mode 1 & $\begin{array}{c}\sigma_{g} \\
\text { Mode 2 }\end{array}$ & Mode 3 & Mode 1 & $\begin{array}{c}N_{i} \text { Mode }^{-3} \text { ] } \\
\text { Mode 3 }\end{array}$ \\
\hline January & - & - & - & - & - & - & - & - & - \\
February & - & - & - & - & - & - & - & - & - \\
March & - & - & - & - & - & - & - & - & - \\
April & - & - & - & - & - & - & - & - & - \\
May & - & - & - & - & - & - & - & - & - \\
June & - & - & - & - & - & - & - & - & - \\
July & - & - & - & - & - & - & - & - & - \\
August & - & - & - & - & - & - & - & - & - \\
September & - & - & - & - & - & - & - & - & - \\
October & - & - & - & - & - & - & - & - & - \\
November & $10.71 \pm 1.48$ & $36.77 \pm 1.35$ & $150.95 \pm 1.40$ & $1.70 \pm 1.12$ & $1.78 \pm 1.08$ & $1.58 \pm 1.12$ & $14371 . \pm 4$. & $8317 . \pm 3$. & $1291 . \pm 2$. \\
December & $9.76 \pm 1.58$ & $38.27 \pm 1.42$ & $145.12 \pm 1.41$ & $1.64 \pm 1.15$ & $1.78 \pm 1.08$ & $1.60 \pm 1.12$ & $17001 . \pm 6$. & $7159 . \pm 3$. & $1393 . \pm 2$. \\
\hline
\end{tabular}

\begin{tabular}{cccccccccc}
\hline 1998 & & $\begin{array}{c}D_{p g}[\mathrm{~nm}] \\
\text { Mode 1 }\end{array}$ & Mode 2 & Mode 3 & Mode 1 & $\begin{array}{c}\sigma_{g} \\
\text { Mode 2 }\end{array}$ & Mode 3 & Mode 1 & $N_{i}\left[\mathrm{~cm}^{-3}\right]$ \\
& Mode 2 & Mode 3 \\
\hline January & $10.73 \pm 1.49$ & $35.14 \pm 1.33$ & $136.25 \pm 1.45$ & $1.72 \pm 1.14$ & $1.77 \pm 1.09$ & $1.58 \pm 1.12$ & $10991 . \pm 4$. & $6789 . \pm 2$. & $1018 . \pm 2$. \\
February & $11.86 \pm 1.32$ & $34.21 \pm 1.30$ & $146.13 \pm 1.40$ & $1.72 \pm 1.09$ & $1.81 \pm 1.07$ & $1.62 \pm 1.14$ & $9108 . \pm 3$. & $7065 . \pm 2$. & $782 . \pm 3$. \\
March & $12.27 \pm 1.32$ & $36.17 \pm 1.31$ & $140.97 \pm 1.43$ & $1.71 \pm 1.09$ & $1.79 \pm 1.08$ & $1.58 \pm 1.14$ & $10918 . \pm 2$. & $9524 . \pm 2$. & $994 . \pm 3$. \\
April & $10.80 \pm 1.35$ & $36.19 \pm 1.42$ & $135.35 \pm 1.41$ & $1.70 \pm 1.10$ & $1.77 \pm 1.09$ & $1.61 \pm 1.13$ & $10984 . \pm 2$. & $7871 . \pm 2$. & $1452 . \pm 2$. \\
May & $10.11 \pm 1.29$ & $34.40 \pm 1.36$ & $126.05 \pm 1.45$ & $1.71 \pm 1.09$ & $1.81 \pm 1.08$ & $1.61 \pm 1.13$ & $8428 . \pm 2$. & $6518 . \pm 2$. & $1072 . \pm 3$. \\
June & $11.73 \pm 1.31$ & $39.89 \pm 1.32$ & $138.25 \pm 1.44$ & $1.72 \pm 1.10$ & $1.78 \pm 1.08$ & $1.56 \pm 1.12$ & $5354 . \pm 2$. & $5964 . \pm 2$. & $1012 . \pm 3$. \\
July & $13.92 \pm 1.34$ & $44.93 \pm 1.35$ & $154.42 \pm 1.42$ & $1.68 \pm 1.10$ & $1.76 \pm 1.09$ & $1.53 \pm 1.13$ & $3890 . \pm 2$. & $4586 . \pm 2$. & $710 . \pm 2$. \\
August & $16.12 \pm 1.24$ & $47.19 \pm 1.23$ & $168.16 \pm 1.39$ & $1.61 \pm 1.08$ & $1.70 \pm 1.07$ & $1.47 \pm 1.10$ & $4528 . \pm 2$. & $4662 . \pm 2$. & $499 . \pm 2$. \\
September & $16.27 \pm 1.26$ & $47.49 \pm 1.28$ & $168.00 \pm 1.34$ & $1.63 \pm 1.09$ & $1.69 \pm 1.09$ & $1.48 \pm 1.10$ & $4723 . \pm 2$. & $5248 . \pm 2$. & $607 . \pm 2$. \\
October & $13.23 \pm 1.39$ & $39.46 \pm 1.35$ & $149.76 \pm 1.36$ & $1.70 \pm 1.09$ & $1.75 \pm 1.08$ & $1.54 \pm 1.13$ & $5740 . \pm 2$. & $4814 . \pm 2$. & $555 . \pm 2$. \\
November & $11.70 \pm 1.32$ & $35.57 \pm 1.34$ & $151.82 \pm 1.42$ & $1.72 \pm 1.09$ & $1.80 \pm 1.08$ & $1.61 \pm 1.14$ & $9544 . \pm 2$. & $7676 . \pm 2$. & $886 . \pm 2$. \\
December & $13.67 \pm 1.25$ & $37.92 \pm 1.29$ & $162.72 \pm 1.33$ & $1.66 \pm 1.07$ & $1.78 \pm 1.08$ & $1.58 \pm 1.13$ & $7735 . \pm 2$. & $5940 . \pm 2$. & $725 . \pm 2$. \\
\hline
\end{tabular}

\begin{tabular}{|c|c|c|c|c|c|c|c|c|c|}
\hline \multirow[t]{2}{*}{1999} & \multicolumn{3}{|c|}{$D_{p g}[\mathrm{~nm}]$} & \multicolumn{3}{|c|}{$\sigma_{g}$} & \multicolumn{3}{|c|}{$N_{i}\left[\mathrm{~cm}^{-3}\right]$} \\
\hline & Mode 1 & & Mode 3 & Mode 1 & & Mode 3 & Mode 1 & Mode 2 & Mode 3 \\
\hline $\mathrm{Ja}$ & $13.51 \pm 1.27$ & & $163.90 \pm 1.35$ & $1.67 \pm 1.08$ & 8 & 3 & & 2. & $=2$. \\
\hline & & & & & & & & & \\
\hline & & & & & & & & & \\
\hline A & 1 & & & & & & & & \\
\hline May & $12.48=$ & 0 & 14 & 10 & 09 & & & & \pm 2 . \\
\hline June & $12.30 \pm 1.30$ & 1250 & & & & 1.5 & & & $1427 . \pm 2$. \\
\hline July & & & & $1.70 \pm$ & $1.70 \pm$ & $1.50 \pm$ & $4276 . \pm 2$ & & $842 . \pm 3$ \\
\hline Augl & & & & & & & & & \\
\hline Septe & & & & & & & & & $1123 . \pm 3$. \\
\hline & & & & & & & & & $664 . \pm 2$ \\
\hline Nov & & & & & & & & & \\
\hline December & $11.65 \pm 1.33$ & $35.27 \pm 1.31$ & $145.09 \pm 1.40$ & $1.76 \pm 1.08$ & $1.81 \pm 1.08$ & $1.61 \pm 1.14$ & $6864 . \pm 3$ & $5598 . \pm 2$ & $734 . \pm 2$. \\
\hline
\end{tabular}




\begin{tabular}{|c|c|c|c|c|c|c|c|c|c|}
\hline \multirow[t]{2}{*}{2000} & \multicolumn{3}{|c|}{$D_{p g}[\mathrm{~nm}]$} & \multicolumn{3}{|c|}{$\sigma_{g}$} & \multicolumn{3}{|c|}{$N_{i}\left[\mathrm{~cm}^{-3}\right]$} \\
\hline & Mode 1 & Mode 2 & Mode 3 & Mode 1 & Mode 2 & Mode 3 & Mode 1 & Mode 2 & Mode 3 \\
\hline January & $12.52 \pm 1.25$ & $35.05 \pm 1.26$ & $148.62 \pm 1.25$ & $1.68 \pm 1.08$ & $1.79 \pm 1.08$ & $1.54 \pm 1.11$ & $6611 . \pm 2$ & $5712 . \pm 2$ & $602 . \pm 2$ \\
\hline February & $13.00 \pm 1.26$ & $36.82 \pm 1.27$ & $150.03 \pm 1.28$ & $1.70 \pm 1.08$ & $1.78 \pm 1.07$ & $1.54 \pm 1.12$ & $5909 . \pm 2$ & 613 & $613 . \pm 2$ \\
\hline March & $10.00 \pm 1.41$ & $29.89 \pm 1.35$ & $128.13 \pm 1.38$ & $1.75 \pm 1.10$ & $1.79 \pm 1.09$ & $1.62 \pm 1.13$ & 10796.土3. & $6568 . \pm 2$ & $939 . \pm 2$ \\
\hline April & $8.70 \pm 1.31$ & $30.85 \pm 1.37$ & $123.95 \pm 1.41$ & $1.70 \pm 1.10$ & $1.80 \pm 1.09$ & $1.66 \pm 1.13$ & $13316 . \pm 2$ & $9287 . \pm 2$ & $1640 . \pm 3$. \\
\hline May & $9.90 \pm 1.36$ & $35.95 \pm 1.39$ & $126.79 \pm 1.48$ & $1.75 \pm 1.10$ & $1.73 \pm 1.11$ & $1.54 \pm 1.13$ & $9196 . \pm 2$ & $7506 . \pm 2$ & $1014 . \pm 3$. \\
\hline June & $10.27 \pm 1.38$ & $38.60 \pm 1.37$ & $126.37 \pm 1.44$ & $1.75 \pm 1.11$ & $1.74 \pm 1.10$ & $1.56 \pm 1.13$ & $6964 . \pm 2$ & 7044.土2 & $1170 . \pm 3$. \\
\hline July & $10.44 \pm 1.39$ & $37.12 \pm 1.39$ & $136.18 \pm 1.40$ & $1.73 \pm 1.10$ & $1.77 \pm 1.10$ & $1.61 \pm 1.13$ & $5519 . \pm 2$ & $5009 . \pm 2$ & $1114 . \pm 2$. \\
\hline August & $10.47 \pm 1.41$ & $36.49 \pm 1.40$ & $126.28 \pm 1.43$ & $1.73 \pm 1.10$ & $1.79 \pm 1.09$ & $1.61 \pm 1.14$ & $6141 . \pm 2$ & $5740 . \pm 2$ & $1325 . \pm 2$ \\
\hline September & $11.28 \pm 1.36$ & $38.23 \pm 1.35$ & $135.43 \pm 1.42$ & $1.74 \pm 1.09$ & $1.80 \pm 1.08$ & $1.59 \pm 1.14$ & $7279 . \pm 2$ & $7160 . \pm 2$ & $1162 . \pm 3$. \\
\hline October & $11.08 \pm 1.32$ & $39.34 \pm 1.42$ & $151.70 \pm 1.34$ & $1.73 \pm 1.09$ & $1.83 \pm 1.07$ & $1.70 \pm 1.13$ & $4272 . \pm 2$ & $4734 . \pm 2$ & $1298 . \pm 2$ \\
\hline November & $10.56 \pm 1.31$ & $38.90 \pm 1.39$ & $160.11 \pm 1.38$ & $1.73 \pm 1.09$ & $1.79 \pm 1.09$ & $1.67 \pm 1.14$ & $4759 . \pm 3$ & $4939 . \pm 3$ & $1037 . \pm 2$ \\
\hline December & $9.93 \pm 1.29$ & $33.58 \pm 1.37$ & $152.70 \pm 1.39$ & $1.71 \pm 1.09$ & $1.81 \pm 1.08$ & $1.67 \pm 1.14$ & $5954 . \pm 2$ & $4923 . \pm 2$ & $897 . \pm 2$ \\
\hline
\end{tabular}

\begin{tabular}{|c|c|c|c|c|c|c|c|c|c|}
\hline \multirow[t]{2}{*}{2001} & \multicolumn{3}{|c|}{$D_{p g}[\mathrm{~nm}]$} & \multicolumn{3}{|c|}{$\sigma_{g}$} & \multicolumn{3}{|c|}{$N_{i}\left[\mathrm{~cm}^{-3}\right]$} \\
\hline & Mode 1 & Mode 2 & Mode 3 & Mode 1 & Mode 2 & Mode 3 & Mode 1 & Mode 2 & Mode 3 \\
\hline January & $9.50 \pm 1.27$ & $29.90 \pm 1.34$ & $130.19 \pm 1.31$ & $1.74 \pm 1.09$ & $1.80 \pm 1.08$ & $1.69 \pm 1.11$ & $6242 . \pm 2$ & 4919.土2. & $1226 . \pm 2$ \\
\hline February & $9.31 \pm 1.28$ & $27.83 \pm 1.30$ & $115.22 \pm 1.27$ & $1.74 \pm 1.09$ & $1.74 \pm 1.08$ & $1.63 \pm 1.10$ & $11793 . \pm 2$ & $8741 . \pm 2$ & $1340 . \pm 2$ \\
\hline March & $9.46 \pm 1.36$ & $29.23 \pm 1.41$ & $123.68 \pm 1.31$ & $1.71 \pm 1.10$ & $1.74 \pm 1.09$ & $1.64 \pm 1.11$ & $12575 . \pm 2$ & $6951 . \pm 2$ & $1395 . \pm 2$ \\
\hline April & $8.17 \pm 1.32$ & $31.00 \pm 1.48$ & $117.70 \pm 1.37$ & $1.69 \pm 1.11$ & $1.77 \pm 1.09$ & $1.64 \pm 1.11$ & $9455 . \pm 3$ & $6449 . \pm 2$ & $1696 . \pm 3$. \\
\hline May & $7.87 \pm 1.33$ & $30.10 \pm 1.43$ & $112.40 \pm 1.36$ & $1.65 \pm 1.11$ & $1.73 \pm 1.10$ & $1.57 \pm 1.11$ & $11821 . \pm 2$ & $6342 . \pm 2$ & $1140 . \pm 3$ \\
\hline June & $7.84 \pm 1.29$ & $32.29 \pm 1.47$ & $109.33 \pm 1.37$ & $1.66 \pm 1.10$ & $1.77 \pm 1.10$ & $1.58 \pm 1.11$ & $9316 . \pm 2$ & $6359 . \pm 2$ & $1887 . \pm 2$ \\
\hline July & $9.17 \pm 1.35$ & $39.00 \pm 1.48$ & $128.81 \pm 1.32$ & $1.68 \pm 1.11$ & $1.75 \pm 1.11$ & $1.57 \pm 1.11$ & $5831 . \pm 2$ & $4716 . \pm 2$ & $1851 . \pm 2$ \\
\hline August & $15.39 \pm 1.38$ & $53.04 \pm 1.37$ & $151.92 \pm 1.45$ & $1.62 \pm 1.11$ & $1.69 \pm 1.10$ & $1.49 \pm 1.11$ & $3272 . \pm 2$ & $3368 . \pm 2$ & $707 . \pm 3$ \\
\hline September & $20.46 \pm 1.28$ & $54.14 \pm 1.32$ & $162.06 \pm 1.41$ & $1.59 \pm 1.09$ & $1.70 \pm 1.09$ & $1.52 \pm 1.10$ & $2650 . \pm 2$ & $2772 . \pm 2$ & $598 . \pm 2$. \\
\hline October & $15.20 \pm 1.23$ & $45.56 \pm 1.30$ & $173.05 \pm 1.40$ & $1.58 \pm 1.09$ & $1.71 \pm 1.08$ & $1.52 \pm 1.12$ & $3940 . \pm 2$ & $4050 . \pm 2$ & $568 . \pm 2$ \\
\hline November & $14.61 \pm 1.24$ & $37.81 \pm 1.37$ & $145.80 \pm 1.30$ & $1.61 \pm 1.08$ & $1.65 \pm 1.09$ & $1.57 \pm 1.10$ & $6590 . \pm 3$ & $3197 . \pm 3$ & $714 . \pm 2$ \\
\hline December & $16.40 \pm 1.21$ & $42.99 \pm 1.30$ & $155.47 \pm 1.28$ & $1.59 \pm 1.07$ & $1.66 \pm 1.09$ & $1.57 \pm 1.10$ & $6853 . \pm 3$ & 4003.土2. & $991 . \pm 2$. \\
\hline
\end{tabular}

\begin{tabular}{|c|c|c|c|c|c|c|c|c|c|}
\hline \multirow[t]{2}{*}{2002} & \multicolumn{3}{|c|}{$D_{p g}[\mathrm{~nm}]$} & \multicolumn{3}{|c|}{$\sigma_{g}$} & \multicolumn{3}{|c|}{$N_{i}\left[\mathrm{~cm}^{-3}\right]$} \\
\hline & ode 1 & Mode 2 & Tode 3 & Mode 1 & Mode 2 & Mode 3 & Mode 1 & Mode 2 & Mode 3 \\
\hline $\mathrm{J}_{\mathrm{i}}$ & 1 & $42.93 \pm 1.42$ & & 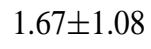 & 0 & 3 & 4. & & 2 . \\
\hline & & & & & & & & & \\
\hline & & & & & & & & & \\
\hline & & & & & & & & & \\
\hline May & & & & & & & & & \\
\hline June & & & & & & & & & \\
\hline July & & & & & & & & & \pm 3 \\
\hline August & $12.70 \pm$ & $47.89 \pm$ & 152. & & $1.76 \pm 1.09$ & $1.54-$ & & 4329.土2. & $1258 . \pm 2$ \\
\hline Septembe & $16.05 \pm 1.27$ & $49.58 \pm 1.37$ & $154.10 \pm 1.36$ & $1.57 \pm 1.10$ & $1.66 \pm 1.10$ & $1.46 \pm 1.08$ & 4823.土2. & $2988 . \pm 2$ & $577 . \pm 3$ \\
\hline October & $18.34 \pm 1.27$ & $50.24 \pm 1.26$ & $177.03 \pm 1.23$ & $1.53 \pm 1.07$ & $1.64 \pm 1.08$ & $1.45 \pm$ & 4577.土2. & $2478 . \pm 2$ & $427 . \pm 2$. \\
\hline Novem & $20.08 \pm 1.16$ & $54.44 \pm 1$ & $184.44 \pm$ & & $1.63 \pm$ & $1.44 \pm$ & $3483 . \pm 3$ & 2038 & $466 . \pm 2$ \\
\hline December & $20.26 \pm 1.17$ & $54.38 \pm 1.24$ & $174.77 \pm 1.22$ & $1.51 \pm 1.07$ & $1.63 \pm 1.07$ & $1.45 \pm 1.07$ & 4045.土3 & $2625 . \pm 3$ & $508 . \pm 2$ \\
\hline
\end{tabular}




\begin{tabular}{cccccccccc}
\hline 2003 & & $\begin{array}{c}D_{p g}[\mathrm{~nm}] \\
\text { Mode 2 }\end{array}$ & Mode 3 & Mode 1 & Mode 2 & Mode 3 & Mode 1 & Mode 2 & Mode 3 \\
\hline January & $20.54 \pm 1.22$ & $52.53 \pm 1.25$ & $173.94 \pm 1.21$ & $1.54 \pm 1.08$ & $1.63 \pm 1.07$ & $1.45 \pm 1.07$ & $5010 . \pm 3$. & $3096 . \pm 3$. & $508 . \pm 2$. \\
February & $19.81 \pm 1.19$ & $56.91 \pm 1.27$ & $174.49 \pm 1.29$ & $1.55 \pm 1.07$ & $1.66 \pm 1.08$ & $1.45 \pm 1.08$ & $4086 . \pm 3$. & $2778 . \pm 3$. & $588 . \pm 2$. \\
March & - & - & - & - & - & - & - & - & - \\
April & - & - & - & - & - & - & - & - & - \\
May & - & - & - & - & - & - & - & - & - \\
June & - & - & - & - & - & - & - & - & - \\
July & - & - & - & - & - & - & - & - & - \\
August & - & - & - & - & - & - & - & - & - \\
September & - & - & - & - & - & - & - & - & - \\
October & - & - & - & - & - & - & - & - & - \\
November & - & - & - & - & - & - & - & - & - \\
December & - & - & - & - & - & - & - & - & - \\
\hline
\end{tabular}

\section{Appendix B}

Monthly statistical values of the total number concentrations $\left[8<D_{p}<400 \mathrm{~nm}\right]$ evaluated from the hourly medians. Arithmetic mean (AM) and standard deviation (STD) are the arithmetic mean and arithmetic standard deviation. $N_{x}$ is the number of events.

\begin{tabular}{cccccccccc}
\hline 1997 & & & & & & & & & \\
& Min. & $5 \%$ & $25 \%$ & Median & $75 \%$ & $95 \%$ & Max. & AM \pm STD & $N_{x}$ \\
\hline January & - & - & - & - & - & - & - & - & - \\
February & - & - & - & - & - & - & - & - & - \\
March & - & - & - & - & - & - & - & - & - \\
April & - & - & - & - & - & - & - & - & - \\
May & 3940 & 7950 & 12400 & 16800 & 23500 & 38200 & 57600 & $19500 \pm 9730$ & 593 \\
June & 1030 & 6150 & 12200 & 17900 & 27300 & 42100 & 59500 & $20500 \pm 11100$ & 649 \\
July & - & - & - & - & - & - & - & - & - \\
August & 4710 & 6750 & 10300 & 15400 & 22900 & 33300 & 53000 & $17600 \pm 8890$ & 247 \\
September & 1130 & 5550 & 10600 & 14700 & 20700 & 32200 & 59400 & $16500 \pm 8630$ & 711 \\
October & 1830 & 6350 & 13100 & 21500 & 32800 & 47500 & 59600 & $23700 \pm 12800$ & 711 \\
November & 1890 & 4250 & 9950 & 18100 & 28500 & 48100 & 59000 & $20800 \pm 13300$ & 663 \\
December & 1700 & 2850 & 7250 & 15300 & 26500 & 47400 & 59700 & $18800 \pm 13900$ & 670 \\
\hline
\end{tabular}

\begin{tabular}{cccccccccc}
\hline 1998 & & & & & & & & & \\
& Min. & $5 \%$ & $25 \%$ & Median & $75 \%$ & $95 \%$ & Max. & AM \pm STD & $N_{x}$ \\
\hline January & 1250 & 3750 & 8050 & 13500 & 25200 & 44400 & 59800 & $18100 \pm 13200$ & 650 \\
February & 1200 & 4050 & 8950 & 14500 & 23500 & 44500 & 59300 & $18100 \pm 12400$ & 587 \\
March & 1870 & 6450 & 13300 & 19500 & 28900 & 44100 & 59200 & $22100 \pm 11800$ & 613 \\
April & 3610 & 6350 & 11800 & 17900 & 26400 & 39900 & 59500 & $20200 \pm 10700$ & 687 \\
May & 2270 & 5950 & 9450 & 13700 & 19300 & 28300 & 52000 & $15300 \pm 7650$ & 743 \\
June & 2290 & 3750 & 7450 & 11100 & 18100 & 31000 & 54100 & $13800 \pm 8920$ & 684 \\
July & 2910 & 4250 & 6250 & 9250 & 12500 & 19600 & 40100 & $10200 \pm 5150$ & 579 \\
August & 1920 & 4150 & 6550 & 9350 & 13800 & 23800 & 48700 & $11100 \pm 6360$ & 742 \\
September & 2330 & 4250 & 7250 & 11100 & 15500 & 24900 & 55300 & $12400 \pm 7130$ & 716 \\
October & 1170 & 3250 & 6450 & 10900 & 16000 & 27800 & 50600 & $12500 \pm 7840$ & 697 \\
November & 2240 & 4250 & 9350 & 16900 & 27000 & 45100 & 59900 & $19800 \pm 13100$ & 702 \\
December & 1850 & 3750 & 8250 & 14200 & 22500 & 38200 & 58600 & $16900 \pm 11200$ & 738 \\
\hline
\end{tabular}




\begin{tabular}{cccccccccc}
\hline 1999 & & & & & & & & \\
& Min. & $5 \%$ & $25 \%$ & Median & $75 \%$ & $95 \%$ & Max. & AM \pm STD & $N_{x}$ \\
\hline January & 1190 & 4350 & 9250 & 15000 & 25800 & 47800 & 59700 & $18900 \pm 12900$ & 703 \\
February & 1620 & 4350 & 10700 & 18400 & 29500 & 46800 & 59800 & $21100 \pm 13200$ & 625 \\
March & 2590 & 4950 & 11100 & 18800 & 28400 & 44100 & 60000 & $20900 \pm 12200$ & 732 \\
April & 2980 & 6350 & 10900 & 15600 & 23100 & 36800 & 58900 & $18200 \pm 9780$ & 714 \\
May & 1670 & 5550 & 9950 & 14600 & 20100 & 32000 & 55500 & $16000 \pm 8130$ & 742 \\
June & 3040 & 4950 & 8650 & 12300 & 18300 & 29200 & 48700 & $14200 \pm 7510$ & 720 \\
July & 2630 & 4350 & 6850 & 9750 & 13300 & 21100 & 39400 & $10900 \pm 5530$ & 744 \\
August & 2440 & 4750 & 8350 & 11800 & 17300 & 29000 & 59400 & $13900 \pm 8070$ & 741 \\
September & 2290 & 5050 & 9250 & 13300 & 18700 & 32700 & 57400 & $15300 \pm 8870$ & 676 \\
October & 1610 & 3750 & 8050 & 12200 & 19200 & 34000 & 53000 & $14900 \pm 9400$ & 724 \\
November & 1300 & 3350 & 6550 & 11100 & 18100 & 32900 & 57000 & $14000 \pm 9800$ & 652 \\
December & 1150 & 3250 & 6650 & 11700 & 21600 & 38500 & 58000 & $15400 \pm 11200$ & 726 \\
\hline
\end{tabular}

\begin{tabular}{cccccccccc}
\hline 2000 & & & & & & & & \\
& Min. & $5 \%$ & $25 \%$ & Median & $75 \%$ & $95 \%$ & Max. & AM \pm STD & $N_{x}$ \\
\hline January & 1740 & 3650 & 7550 & 12700 & 19700 & 30500 & 48500 & $14500 \pm 8720$ & 712 \\
February & 2220 & 4450 & 7850 & 12300 & 18800 & 29400 & 46900 & $14200 \pm 7990$ & 445 \\
March & 2150 & 4550 & 9450 & 15900 & 24200 & 38600 & 59800 & $17800 \pm 10600$ & 712 \\
April & 2830 & 6550 & 12800 & 18800 & 29600 & 45900 & 58800 & $21900 \pm 12200$ & 681 \\
May & 4770 & 7050 & 11400 & 15400 & 22600 & 34200 & 53700 & $17700 \pm 8580$ & 708 \\
June & 3300 & 6050 & 9650 & 13800 & 20000 & 32900 & 58500 & $16000 \pm 8660$ & 690 \\
July & 1410 & 3950 & 6550 & 10200 & 16400 & 28300 & 46100 & $12600 \pm 8020$ & 665 \\
August & 2480 & 4650 & 8350 & 12200 & 17100 & 29100 & 49500 & $13800 \pm 7400$ & 736 \\
September & 3940 & 6450 & 9650 & 14400 & 19700 & 33600 & 56400 & $16100 \pm 8670$ & 652 \\
October & 1450 & 3050 & 6550 & 9550 & 14300 & 23200 & 55400 & $11200 \pm 7070$ & 594 \\
November & 1020 & 2650 & 5050 & 8950 & 16700 & 33400 & 59900 & $12400 \pm 10300$ & 712 \\
December & 1340 & 2850 & 5850 & 9950 & 17500 & 30500 & 55400 & $12700 \pm 9170$ & 709 \\
\hline
\end{tabular}

\begin{tabular}{cccccccccc}
\hline 2001 & & & & & & & & & \\
& Min. & $5 \%$ & $25 \%$ & Median & $75 \%$ & $95 \%$ & Max. & AM \pm STD & $N_{x}$ \\
\hline January & 1280 & 2250 & 6050 & 10600 & 17800 & 32000 & 55600 & $13200 \pm 9570$ & 689 \\
February & 2610 & 5250 & 10900 & 17600 & 27100 & 43600 & 58700 & $20200 \pm 11900$ & 624 \\
March & 2990 & 5550 & 10400 & 15700 & 25900 & 43700 & 58300 & $19300 \pm 11800$ & 718 \\
April & 2360 & 4350 & 7950 & 12400 & 21800 & 41300 & 57500 & $16400 \pm 11400$ & 669 \\
May & 2880 & 5650 & 9450 & 13500 & 19300 & 35500 & 58100 & $15900 \pm 9400$ & 740 \\
June & 3820 & 5150 & 8350 & 13300 & 20200 & 39100 & 59500 & $16200 \pm 10600$ & 712 \\
July & 2580 & 4450 & 7250 & 10600 & 15400 & 27600 & 54600 & $12700 \pm 7640$ & 703 \\
August & 1320 & 3450 & 5250 & 7350 & 10900 & 19000 & 50600 & $8980 \pm 5500$ & 506 \\
September & 1180 & 2250 & 4250 & 6850 & 9350 & 15500 & 39100 & $7540 \pm 4430$ & 576 \\
October & 1460 & 3050 & 5050 & 8450 & 13000 & 25300 & 57200 & $10400 \pm 7480$ & 698 \\
November & 1050 & 2450 & 5250 & 10500 & 18800 & 39800 & 58800 & $14000 \pm 11600$ & 665 \\
December & 1030 & 2850 & 6150 & 12100 & 21200 & 41800 & 59600 & $15600 \pm 12100$ & 737 \\
\hline
\end{tabular}




\begin{tabular}{cccccccccc}
\hline 2002 & & & & & & & & & \\
& Min. & $5 \%$ & $25 \%$ & Median & $75 \%$ & $95 \%$ & Max. & AM \pm STD & $N_{x}$ \\
\hline January & 1190 & 2050 & 4250 & 8650 & 19800 & 37700 & 59400 & $13500 \pm 12000$ & 722 \\
February & 1300 & 2650 & 5050 & 9150 & 17400 & 38100 & 59100 & $13100 \pm 11000$ & 640 \\
March & 1410 & 3150 & 6150 & 9750 & 15800 & 32400 & 59900 & $12600 \pm 9620$ & 737 \\
April & 2060 & 5350 & 8550 & 12700 & 17800 & 34400 & 58900 & $15000 \pm 9360$ & 704 \\
May & 1690 & 4250 & 8050 & 11800 & 15400 & 29300 & 53100 & $13200 \pm 7760$ & 728 \\
June & 2100 & 3550 & 5950 & 8750 & 12000 & 20200 & 36900 & $9860 \pm 5330$ & 688 \\
July & 2380 & 3550 & 6150 & 9650 & 14400 & 30300 & 50900 & $11900 \pm 8210$ & 741 \\
August & 2650 & 4050 & 6750 & 10500 & 14800 & 29800 & 57000 & $12200 \pm 7910$ & 643 \\
September & 1130 & 3250 & 5450 & 8850 & 13300 & 26100 & 55300 & $10800 \pm 7550$ & 705 \\
October & 1210 & 2450 & 5050 & 8050 & 12200 & 22800 & 48100 & $9680 \pm 6610$ & 738 \\
November & 1040 & 1550 & 3650 & 6750 & 12200 & 23400 & 38000 & $9000 \pm 7050$ & 709 \\
December & 1050 & 1450 & 3750 & 8050 & 15900 & 32500 & 57400 & $11400 \pm 9980$ & 694 \\
\hline
\end{tabular}

\begin{tabular}{cccccccccc}
\hline 2003 & Min. & $5 \%$ & $25 \%$ & Median & $75 \%$ & $95 \%$ & Max. & AM \pm STD & $N_{x}$ \\
\hline January & 1080 & 2150 & 5150 & 10700 & 18200 & 30700 & 58500 & $13000 \pm 9930$ & 742 \\
February & 1010 & 1850 & 4150 & 8350 & 16000 & 30800 & 52400 & $11400 \pm 9290$ & 548 \\
March & - & - & - & - & - & - & - & - & - \\
April & - & - & - & - & - & - & - & - & - \\
May & - & - & - & - & - & - & - & - & - \\
June & - & - & - & - & - & - & - & - & - \\
July & - & - & - & - & - & - & - & - & - \\
August & - & - & - & - & - & - & - & - & - \\
September & - & - & - & - & - & - & - & - & - \\
October & - & - & - & - & - & - & - & - & - \\
November & - & - & - & - & - & - & - & - & - \\
December & - & - & - & - & - & - & - & - & - \\
\hline
\end{tabular}


Acknowledgements. We forward our thanks to The Finnish Meteorological Institute (FMI) for providing the weather data from 1 January 1997 to 31 October 2002. We also thank P. Paatero from the Department of Physical Sciences of the University of Helsinki for his programming advice and optimization of the multi-lognormal fitting, and I. K. Koponen for fruitful discussions.

Edited by: S. Houweling

\section{References}

Adachi, M., Okuyama, K., Kousaka, Y., Moon, S. W., and Seinfeld, J. H.: Facilitated aerosol sizing using the differential mobility analyser, Aerosol Sci. Technol., 12, 225-239, 1990.

Arimoto, R., Duce, R., Ray, B., Ellis, W., Cullen, J., and Merril, J.: Trace elements in the atmosphere over the North Atlantic, J. Geophys. Res., 100, 1199-1213, 1995.

Birmili, W., Stratmann, F., and Wiedensohler, A.: Design of a DMA-based size spectrometer for large particle size range and stable operation, J. Aerosol Sci., 30, 549-553, 1999.

Birmili, W., Wiedensohler, A., Heintzenberg, J., and Lehmann, K.: Atmospheric particle number size distribution in central Europe: statistical relations to air masses and meteorology, J. Geophys. Res., 106(D23), 32 005-32 018, 2001.

Buzorius, G., Hämeri, K., Pekkanen, J., and Kulmala, M.: Spatial variation of aerosol number concentration in Helsinki city, Atmos. Environ., 33, 553-565, 1999.

Dockery, D. W. and Pope, C.: Acute respiratory effects of particulate air pollution, Annual Review of Public Health, 15, 107-132, 1994.

Finlayson-Pitts, B. J. and Pitts Jr., J. N.: Chemistry of the upper and lower atmosphere, Academic Press, San Diego, 2000.

Farnz, B., Eckhardt, T., Kauffeldt, T., and Roth, P.: $\mathrm{H}_{2} \mathrm{O}_{2}$ addition to diesel engine exhaust gas and its effect on particles, J. Aerosol Sci., 31, 415-426, 2000.

Harris, S. J. and Maricq, M. M.: Signature size distributions for diesel and gasoline engine exhaust particulate matter, J. Aerosol Sci., 32, 749-764, 2001

Harrison, R. M., Jones, M., and Collins, G.: Measurements of the physical properties of particles in the urban atmosphere, Atmos. Environ., 33, 309-321, 1999.

Havasi, Á. and Zlatev, Z.: Trends of Hungarian air pollution levels on a long time-scale, Atmos. Environ., 36, 4145-4156, 2002.

Hussein, T., Hämeri, K., and Kulmala, M.: Long-term indooroutdoor aerosol measurement in Helsinki, Finland, Boreal Environ. Res., 7, 141-150, 2002.

Jokinen, V. and Mäkelä, J. M.: Closed-loop arrangement with critical orifice for DMA sheath/excess flow system, J. Aerosol Sci., 28, 643-648, 1997.

Jung, C. H., Kim, Y. P., and Lee, K. W.: Simulation of the influence of coarse mode particles on the properties of fine mode particles, Aerosol Sci. Technol., 33, 1201-1216, 2002.

Katsouyanni, K., Touloumi, G., Samoli, E., Gryparis, A., LeTertre, A., Monopolis, Y., Rossi, G., Zmirou, D., Ballester, F., Boumghar, A., Anderson, H., Wojtyniak, B., Paldy, A., Braunstein, R., and Pekkanen, J. S.: Confounding and effect modification in the short-term effects of ambient particles on total mortality: results from 29 European cities within the APHEA2 project, Epidemiology, 12, 521-531, 2001
Kesten, J., Reineking, A., and Porstendörfer, J.: Calibration of a TSI Model 3025 Ultrafine Condensation Particle Counter, Aerosol Sci. Technol., 15, 107-111, 1991.

Kimmel, V., Tammet, H., and Truuts, T.: Variation of atmospheric air pollution under conditions of rapid economic changes - Estonia 1994 - 1999, Atmos. Environ., 36, 4133-4144, 2002.

Kittelson, D. B.: Engines and nanoparticles: a review, J. Aerosol Sci., 29, 575-588, 1998.

Knutson, E. O. and Whitby, K. T.: Aerosol classification by electric mobility: apparatus, theory and applications, J. Aerosol Sci., 6, 443-451, 1975.

Kulmala, M., Dal Maso, M., Mäkelä, J. M., Pirjola, L., Väkevä, M., Aalto, P., Miikkulainen, P., Hämeri, K., and O’Dowd, C. D.: On the formation, growth and composition of nucleation mode particles, Tellus, 53B, 479-490, 2001.

Kulmala, M., Rannik, Ü., Pirjola, L., Dal Maso, M., Karimäki, J., Asmi, A., Jäppinen, A., Karhu, V., Korhonen, H., Mälvikko, S. P., Puustinen, A., Raittila, J., Romakkaniemi, S., Suni, T., and Yli-Koivisto, S.: Characterization of atmospheric trace gas and aerosol concentrations at forest sites in southern and northern Finland using back trajectories, Boreal Environ. Res., 5, 315336, 2000.

Kulmala, M., Vehkamäki, H., Petäjä, T., Dal Maso, M., Lauri, A., Kerminen, V.-M., Birmili, W., and McMurry, P. H.: Formation and growth rates of ultrafine atmospheric particles: a review of observations. J. Aerosol Sci., 35, 143-176, 2004.

Laakso, L., Hussein, T., Aarnio, P., Komppula, M., Hiltunen, V., Viisanen, Y., and Kulmala, M.: Diurnal and annual characteristics of particle mass and number concentrations in urban, rural and Arctic environments in Finland, Atmos. Environ., 37, 2629 2641, 2003.

Lilleberg, I. and Hellman, T.: Liikenteen kehitys Helsingissä vuonna 2002, Helsingin kaupunkisuunnitteluviraston julkaisuja (in Finnish), 2, 2003.

Liu, B. Y. H. and Pui, D. Y. H.: Electrical neutralization of aerosols, J. Aerosol Sci., 5, 465-472, 1974.

Mertes, S., Schröder, F., and Wiedensohler, A.: The particle detection efficiency curve of the TSI $3010 \mathrm{CPC}$ as a function of the temperature difference between saturator and condenser, Aerosol Sci. Technol., 23, 257-261, 1995.

Morawska, L., Bofinger, N. D., Kocis, L., and Nwankwoala, A.: Submicrometer and supermicrometer particles from diesel vehicle emissions, Environ. Sci. and Tech., 32, 2033-2042, 1998a.

Morawska, L., Jayaratne, E. R., Mengersen, K., Jamriska, M., and Thomas, S.: Differences in airborne particle and gaseous concentrations in urban air between weekdays and weekends, Atmos. Environ., 36, 4375-4383, 2002.

Morawska, L., Thomas, S., Bofinger, N., Wainwright, D., and Neale, D.: Comprehensive characterization of aerosols in a subtropical urban atmosphere: particle size distribution and correlation with gaseous pollutants, Atmos. Environ., 32, 2467-2478, 1998b.

Mäkelä, J. M., Aalto, P., Jokinen, V., Pohja, T., Nissinen, A., Palmroth, S., Markkanen, T., Seitsonen, K., Lihavainen, H., and Kulmala, M.: Observations of ultrafine aerosol particle formation and growth in boreal forest, Geophys. Res. Lett., 24, 1219-1222, 1997.

Mäkelä, J., Hämeri, K., Väkevä, M., Aalto, P., Laakso, L., Kulmala, M., and Charlson, R.: On the spatial scale of the new aerosol 
particle formation in southern Finland, J. Aerosol Sci., 29, S215S216, 1998

Mäkelä, J. M., Koponen, I. K., Aalto, P., and Kulmala, M.: Oneyear data of submicron size modes of tropospheric background aerosols in southern Finland, J. Aerosol Sci., 31, 596-611, 2000.

Nilsson, E., Paatero, J., and Boy, M.: Effects of air masses and synoptic weather on aerosol formation in continental boundary layer, Tellus, 53B, 462-478, 2001.

Peters, A., Wichmann, H. E., Tuch, T., Heinrich, J., and Heyder, J.: Respiratory effects are associated with the number of ultrafine particles, American Journal of Respiratory and Critical Care Medicine, 155, 1376-1383, 1997.

Pohjola, M., Kousa, A., Aarnio, P., Koskentalo, T., Kukkonen, J., Härkönen, J., and Karppinen, A.: Meteorological interpretation of measured urban $\mathrm{PM}_{2.5}$ and $\mathrm{PM}_{10}$ concentrations in the Helsinki metropolitan area. In: Air pollution VIII, edited by Longhurst, J., Brebbia, C., Power, J., Wessex Institute of Technology Press, Southampton, UK, pp. 689-698, 2000.

Pope III, C. A. and Dockery, D. W.: Epidemiology of particle effects, Air Pollution and Health, 31, 673-705, 1999.

Quant, F. R., Caldow, R., Sem, G. J., and Addison, T. J.: Performance of condensation particle counters with three continuousflow designs, J. Aerosol Sci., 23, S405-S408, 1992.

Ruuskanen, J., Tuch, T. H., Brink, H. T., Peters, A., Khlystov, A., Mirme, A., Kos, G. P. A., Brunekreef, B., Wickmann, H. E., Buzorius, G., Vallius, M., Kreyling, W. G., and Pekkanen, J.: Concentrations of ultrafine, fine and $\mathrm{PM}_{2.5}$ particles in three European cities, Atmos. Environ., 35, 3729-3738, 2001.

Samet, J., Dominici, F. C., Coursac, I., and Zeger, S.: Fine particulate air pollution and mortality in 20 U.S. cities, 1987-1994, New England Journal of Medicine, 343, 1742-1749, 2000.

Seinfeld, J. H. and Pandis, S. N.: Atmospheric chemistry and physics: from air pollution to climate change, John Wiley \& Sons, United States of America, 1998.

Shi, J. P., Evans, D. E., Khan, A. A., and Harrison, R. H.: Sources and concentration of nanoparticles ( $<10 \mathrm{~nm}$ diameter) in the urban atmosphere, Atmos. Environ., 35, 1193-1202, 2001.

Stolzenburg, M. R.: An Ultrafine Aerosol Size distribution system, Ph.D. thesis, University of Minnesota, Minneapolis, MN, 1988.

Thomas, S. and Morawska, L.: Size-selected particles in an urban atmosphere of Brisbane, Australia, Atmos. Environ., 36, 42774288, 2002.

Tiitta, P., Raunemaa, T., Tissari, J., Yli-Tuomi, T., Leskinen, A., Kukkonen, J. J. H., and Karppinen, A.: Measurements and modelling of $\mathrm{PM}_{2.5}$ concentrations near a major road in Kuopio, Finland, Atmos. Environ., 36, 4057-4068, 2002.

Tunved, P., Hansson, H.-C., Kulmala, M., Aalto, P., Viisanen, Y.,
Karlsson, H., Kristensson, A., Swietlicki, E., Dal Maso, M., Ström, J., and Komppula, M.: One year boundary layer aerosol size distribution data from five Nordic background stations, Atmos. Chem. Phys., 3, 2183-2205, 2003.

Turco, R. P. and Fangqun, Y.: Particle size distributions in an expanding plume undergoing simultaneous coagulation and condensation, J. Geophys. Res., 104, 19227-19241, 1999.

Vallius, M., Lanki, T., Tiitta, P., Koistinen, K., Ruuskanen, J., and Pekkanen, J.: Source apportionment of urban ambient $\mathrm{PM}_{2.5}$ in two successive measurement campaigns in Helsinki, Finland, Atmos. Environ., 37, 615-623, 2002.

Väkevä, M., Hämeri, K., Kulmala, M., Lahdes, R., Ruuskanen, J., and Laitinen, T.: Street level versus rooftop concentrations of submicron aerosol particles and gaseous pollutants in an urban street canyon, Atmos. Environ., 33, 1385-1397, 1999.

Väkevä, M., Hämeri, K., Puhakka, T., Nilsson, E., Hohti, K., and Mäkelä, J.: Effects of meteorological processes on aerosol particle size distribution in an urban background area, J. Geophys. Res., 105, 9807-9821, 2000.

Wehner, B., Birmili, W., Gnuak, T., and Wiedensohler, A.: Particle number size distributions in a street canyon and their transformation into the urban-air background: measurements and a simple model study, Atmos. Environ., 36, 2215-2223, 2002.

Wehner, B. and Wiedensohler, A.: Long term measurements of submicrometer urban aerosols: statistical analysis for correlations with meteorological conditions and trace gases, Atmos. Chem. Phys., 3, 867-879, 2003

Wiedensohler, A.: Die bipolare Diffusionsaufladung von Partikeln in chemisch trägen Reinstgasen, Ph.D. thesis, University of Duisburg, Germany, 1989.

Winklmayr, W., Reischl, G. P., Lindner, A. O., and Berner, A.: A new electromobility spectrometer for the measurement of aerosol size distributions in the size range from 1 to $1000 \mathrm{~nm}$, J. Aerosol. Sci., 22, 289-296, 1991.

Wu, Y., Hao, J., Fu, L., Wang, Z., and Tang, U.: Vertical and horizontal profiles of airborne particulate matter near major roads in Macao, China, Atmos. Environ., 36, 4907-4918, 2002.

Yang, K.-L.: Spatial and seasonal variation of $\mathrm{PM}_{10}$ mass concentrations in Taiwan, Atmos. Environ., 36, 3403-3411, 2002.

Zhang, X. Y., Cao, J. J., Li, L. M., Arimoto, R., Cheng, Y., Huebert, B., and Wang, D.: Characterization of atmospheric aerosol over XiAn in the south margin of the Loess Plateau, China, Atmos. Environ., 36, 4189-4199, 2002.

Zhang, K. M. and Wexler, A. S.: Modeling the number distributions of urban and regional aerosols: theoretical foundations, Atmos. Environ., 36, 1863-1874, 2002. 